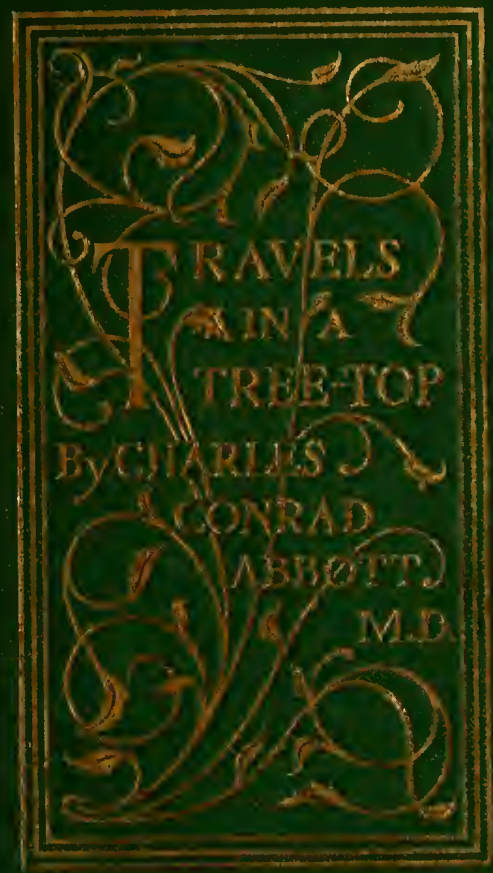




\section{LIBRARY OF CONGRESS,}

Chtratt

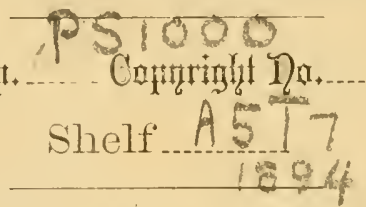

UNITED STATES OF AHERICA. 








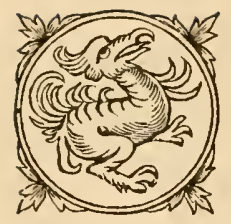


By Dr. Aвbott

RECENT RAMBLES; OR, In Touch with Nature.

Crown 8vo. Gilt top. Illus-

trated. $\$ 2.00$ 
TRAVELS IN

$A$ TREE-TOP 



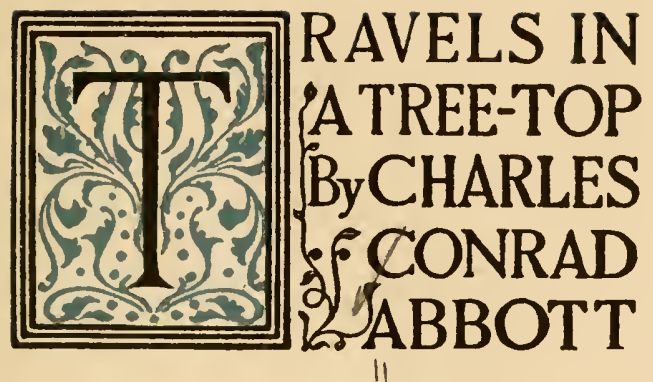

PHILADELPHIA \& LON-

DON: J.B.LIPPINCOTT COMPANY: MDCCCXCIV

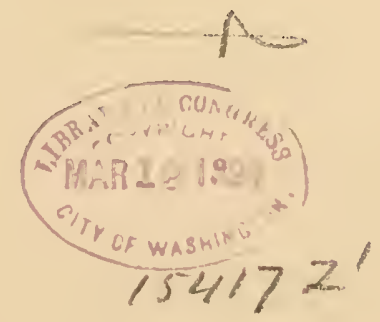




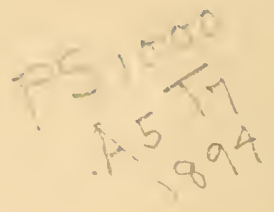

Copyright, 1894 ,

BY

J. B. Lippincott Company.

Printed ay J. B. Lippincott Company, Philadelphia. 


\section{Contents}

Page

Travels in a Tree-top . . . . . 9

A Hunt for the Pyxie . . . . . 6r

The Coming of the Birds . . . . 7 I

The Building of the Nest . . . . 83

Corn-stalk Fiddles. . . . . . 97

The Old Kitcben Door . . . . . 103

Up the Creek. . . . . . . . 109

A Winter-Nigbt's Outing . . . . . 19

Wild Life in Water . . . . . . 125

An Old-fasbioned Garden . . . . 133

An Indian Trail . . . . . . 147

A Pre-Columbian Dinner . . . . 155

A Day's Digging . . . . . . ${ }^{167}$

Drifting ........ ${ }^{173}$

Footprints . . . . . . 187

Bees and Buckwbeat ....... 195

Dead Leaves . . . . . . . 203 



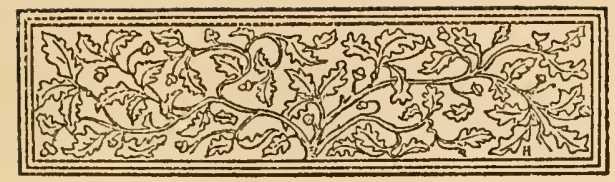

CHAPTER

FIRST

\section{TRAVELS IN A TREE-TOP}

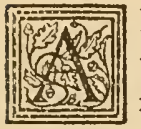

PEARLY mist shut out the river, the meadows, and every field for miles. I could not detect the ripple of the outgoing tide, and the heartiest songster sent no cheerful cry above the wide-spreading and low-lying cloud; but above all this silent, desolate, and seemingly deserted outlook there was a wealth of sunshine and a canopy of deep-blue sky. Here and there, as islands in a boundless sea, were the leafy tops of a few tall trees, and these, I fancied, were tempting regions to explore. Travels in a tree-topsurely, here we have a bit of novelty in this worn-out world.

Unless wholly wedded to the town, it is not cheering to think of the surrounding country as worn out. It is but little more than two centuries since the home-seeking folk of other lands came here to trick or trade with the 
Indians, wild as the untamed world wherein they dwelt; and now we look almost in vain for country as Nature fashioned it. Man may make of a desert a pleasant place, but he also unmakes the forest and bares the wooded hills until as naked and desolate as the fire-swept ruins of his own construction. It is but a matter of a few thousand cart-loads of the hill moved to one side, and the swamp that the farmer dreads because it yields no dollars is obliterated. He has never considered its wealth of suggestiveness. "A fig for the flowers and vermin. I must plant more corn."

But here and there the tall trees are still standing, and their tops are an untravelled country. I climbed an oak this cool midsummer morning; clambered beyond the mists, which were rolling away as I seated myself far above the ground, safe from intrusion, and resting trustfully on yielding branches that moved so gently in the passing breeze that I scarcely perceived their motion.

How much depends upon our point of view! The woodland path may not be charming if the undergrowth too closely shuts us in. In all we do, we seek a wider vision than our arm's length. There may be nothing better 


\section{Travels in a Tree-top}

beyond than at our feet, but we never believe it. It is as natural to ask of the distant as of the future. They are closely akin. Here in the tree-top my wants were supplied. I was only in the least important sense cribbed, cabined, and confined.

Wild life, as we call it, is very discriminating, and that part of it which notices him at all looks upon man as a land animal; one that gropes about the ground, and awkwardly at that, often stumbling and ever making more noise than his progress calls for; but when perched in a tree, as an arboreal creature, he is to be studied anew. So, at least, thought the crows that very soon discovered my lofty quarters. How they chattered and scolded! They dashed near, as if with their ebon wings to cast a spell upon me, and, craning their glossy necks, spoke words of warning. My indifference was exasperating at first, and then, as I did not move, they concluded I was asleep, dead, or a dummy, like those in the cornfields. The loud expostulations gave place to subdued chatterings, and they were about to leave without further investigation, when, by the pressure of my foot, I snapped a dead twig. I will not attempt description. Per- 


\section{Travels in a Tree-top}

haps to this day the circumstance is discussed in corvine circles.

It is difficult to realize the freedom of flight. Twisting and turning with perfeet ease, adapting their bodies to every change of the fitful wind, these crows did not use their wings with that incessant motion that we need in using our limbs to walk, but floated, rose and fell, as if shadows rather than ponderable bodies. Until we can fly, or, rather, ride in flying-machines, we cannot hope to know much of this flight-life of birds, and it is the better part of their lives. But it was something to-day to be with even these crows in the air. Following their erratic flight from such a point of view, I seemed to be flying. We are given at times to wonder a great deal about birds, and they have equal reason to constantly consider us. Who can say what these crows thought of me? All I can offer to him who would solve the problem is that their curiosity was unbounded, and this is much if their curiosity and ours are akin. Of course they talked. Garner need not have gone to Africa to prove that monkeys talk, and no one can question that crows utter more than mere alarm-cries. 


\title{
Travels in a Tree-top
}

A word more concerning crows. What so absurd, apparently, as this ?

\author{
"A single crow betokens sorrow, \\ Two betoken mirth, \\ Three predict a funeral, \\ And four a birth."
}

Yet it is a very common saying, being repeated whenever a few, or less than five, fly over. It is repeated mechanically, of course, and then forgotten, for no one seems to worry over one or three crows as they do when a looking-glass breaks or the dropped fork sticks up in the floor. Seems to worry, and yet I strongly suspect a trace of superstition lingers in the mind of many a woman. These who will not sit as one of thirteen at a table are not dead yet. Can it be that all this weakness is only more concealed than formerly, but none the less existent?

I watched the departing crows until they were but mere specks in the sky, and heard, or fancied I heard, their cawing when half a mile away. It is ever a sweet sound to me. It means so much, recalls a long round of jolly years; and what matters the quality of a sound if a merry heart prompts its utterance? 


\section{I4 Travels in a Tree-top}

I was not the only occupant of the tree; there were hundreds of other and more active travellers, who often stopped to think or converse with their fellows and then hurried on. I refer to the great, shining, black ants that have such a variety of meaningless nicknames. Its English cousin is asserted to be ill-tempered, if not venomous, and both Chaucer and Shakespeare refer to them as often mad and always treacherous. I saw nothing of this to-day. They were ever on the go and always in a hurry. They seemed not to dissociate me from the tree; perhaps thought me an odd excrescence and of no importance. No one thinks of himself as such, and I forced myself upon the attention of some of the hurrying throng. It was easy to intercept them, and they grew quickly frantic; but their fellows paid no attention to such as I held captive for the moment. I had a small paper box with me, and this I stuck full of pin-holes on every side and then put half a dozen of the ants in it. Holding it in the line of the inseets' march, it immediately became a source of wonderment, and every ant that came by stopped and parleyed with the prisoners. A few returned earthward, and then a number 


\section{Travels in a Tree-top}

came together, but beyond this I could see nothing in the way of concerted action on the part of the ants at large looking towards succoring their captive fellows. Releasing them, these detained ants at once scattered in all directions, and the incident was quickly forgotten. Where were these ants going, and what was their purpose? I wondered. I was as near the tree's top as I dared to go, but the ants went on, apparently to the very tips of the tiniest twigs, and not one that I saw came down laden or passed up with any burden. It is not to be supposed they had no purpose in so doing, but what? There is scarcely an hour when we are not called upon to witness just such aimless activity, - that is, aimless so far as we can determine.

Nothing molested these huge black ants, although insect-eating birds came and went continually. One lordly, great-crested flycatcher eyed them meditatively for some seconds, and then my identity suddenly dawned upon him. His harsh voice, affected by fear, was more out of tune than ever, and, coupled with his precipitant flight, was very amusing. The bird fell off the tree, but quickly caught himself, and then, as usual, curiosity overcame 


\section{I6 Travels in a Tree-top}

fear. Students of bird-ways should never forget this. The fly-catcher soon took a stand wherefrom to observe me, and, if intently staring at me for thirty seconds was not curiosity, what shall we call it? Is it fair to explain away everything by calling it mere coincidence? It is a common practice, and about as logical as the old cry of "instinct" when I went to school. To have said, when I was a boy, that a bird could think and could communicate ideas to another of its kind, would have brought down ridicule upon my head out of school, and brought down something more weighty if the idea had been expressed in a "composition." I speak from experience.

To return to the cheerier subject of curiosity in birds: our large hawks have it to a marked degree, and advantage can be taken of this fact if you wish to trap them. I have found this particularly true in winter, when there is a general covering of the ground with snow. Food, of course, is not then quite so plenty, but this does not explain the matter. An empty steel trap on the top of a hay-stack is quite as likely to be tampered with as when baited with a mouse. The hawk will walk 


\section{Travels in a Tree-top}

all around it, and then put out one foot and touch it here and there. If we can judge from the bird's actions, the question, What is it, anyway? is running through its mind. I once played a trick upon a splendid black hawk that had been mousing over the fields for half the winter. It often perched upon a stack of straw instead of the lone hickory near by. Early one morning I placed a plump meadowmouse on the very top of the stack, to which I had attached a dozen long strands of brightred woollen yarn and a bladder that I had inflated. This was secured to the mouse by a silk cord, and all were so concealed by the snow and straw that the hawk noticed the mouse only. The bird was suspicious at first: it was too unusual for a mouse not to move when a hawk hovered above it. Then the bird alighted on the stack and walked about the mouse, pecking at it once, but not touching it. Then putting out one foot, he seized it with a firm grip, the talons passing through the carcass, and at the same time spread his wings and moved slowly towards the lone hickory that towered near by. I was near enough to see every movement. It was evident that the hawk did not look down at first, 
and saw nothing of the streaming threads and bobbing bladder; but it did a moment later, and then what a quickening of wings and hasty mounting upward! The hawk was frightened, and gave a violent jerk with one foot, as if to disengage the mouse, but it was ineffectual. The sharp claws had too strong a hold, and the effect was only to more violently bob the bladder. Then the hawk screamed and dashed into the trees near by, and was out of sight.

A curious and disappointing occurrence, while sitting aloft, was the frequent discovery of my presence by birds and their sudden right-about movement and departure. Occasionally I could see them coming as if directly towards me, but their keen eyes noticed the unusual object, and they would dart off with a promptness that showed how completely at home they were while on the wing. Even the bluebirds, usually so tame, had their misgivings, and came to rest in other trees. But if the birds were not always about and above me, there were many below, and the sweet song of the wood-robin from the tangled underbrush seemed clearer and purer than when sifted through a wilderness of leaves. 


\section{Travels in a Tree-top}

It was not until noon that the wood and open fields became silent or nearly so, for the red-eye came continually, and, whether insecthunting in the tree or on the wing, it seemed never to cease its singing, or querulous cry, which more aptly describes its utterance. To hear this sound throughout a long summer day is depressing, particularly if you hear nothing else, for the steady hum of insect-life hardly passes for sound. It was only when I listened for it that I was aware that millions of tiny creatures were filling the air with a humming that varied only as the light breeze carried it away or brought it nearer and clearer than before. There is a vast difference between absolute and comparative or apparent silence. The former is scarcely ever a condition of the open country unless during a still, cold winter night, and never of one of our ordinary woodland tracts. We do find it, however, in the cedar swamps and pine-land, even during summer. I have often stood in "the pines" of Southern New Jersey and tried to detect some sound other than that of my own breathing, but in vain. Not a twig stirred. The dark waters of the pools were motionless; even the scattered clouds 
above were at rest. It was to be absolutely alone, as if the only living creature upon earth. But ere long a gentle breeze would spring up, there was a light and airy trembling of the pines, and the monotone of a whispered sigh filled the forest. Even this was a relief, and what a joy if some lonely bird passed by and even lisped of its presence! The dee-dee of a titmouse at such a time was sweeter music than the choral service that heralds the coming of a bright June morning.

At noon, the day being torrid, there was comparative silence, and yet as I looked about me I saw ceaseless activity in a small way. The ants were still journeying, and red admiral and yellow swallow-tailed butterflies came near, and the latter even passed high overhead and mingled with the chimneyswifts. Had I been on the ground, walking instead of waiting, I should have sought some sheltered spot and rested, taking a hint from much of the wild life I was watching.

\section{AT NOONTIDE.}

Where cluster oaks and runs the rapid brook, Repose the jutting rocks beneath the ferns; Here seeks the thrush his hidden leafy nook, And wandering squirrel to his hole returns. 


\section{Travels in a Tree-top}

A far the steaming river slowly wends

Its tortuous way to mingle with the sea;

No cheerful voice its languid course attends;

The blight of silence rests upon the lea.

Where the wide meadow spreads its wealth of weeds,

Where the rank harvest waves above the field,

The testy hornet in his anger speeds,

And stolid beetle bears his brazen shield.

Give them the glowing, fiery world they love,

Give me the cool retreat beside the stream;

While sweeps the sun the noontide sky above,

Here would I linger with the birds and dream.

And now what of the tree itself? Here I have been the better part of a long forenoon, and scarcely given this fine young oak a thought. A young oak, yet a good deal older than its burden; an oak that was an acorn when the century was new, and now a sturdy growth full sixty feet high, straight of stem to its undermost branches and shapely everywhere. Such trees are not remarkable of themselves, though things of beauty, but at times how suggestive! Think of preColumbian America; then there were oaks to make men marvel. "There were giants in those days." Occasionally we meet with 
them even now. A year ago I camped on the shore of Chesapeake Bay near an oak that measured eighteen feet six inches in circumference four feet from the ground, and in St. Paul's church-yard, not a great way off, are five big oaks, one of which is twenty feet around shoulder high from the roots. Such trees are very old. The church-yard was enclosed two centuries ago, and these were big trees then, and so older by far than any monument of white men on the continent, except possible traces of the Norsemen. If a tree such as this in which I have been sitting is full to overflowing with suggestiveness, how much more so a noble patriarch like that upon the bay shore! It is usually not easy to realize the dimensions of a huge tree by merely looking at it, but this mammoth impressed one at first sight. The branches were themselves great trees, and together cast a circular patch of shade, at noon, three paces more than one hundred feet across. As a tree in which to ramble none could have been better shaped. The lowest branches were less than twenty feet from the ground, and after reaching horizontally a long way, curved upward and again outward, dividing 


\section{Travels in a Tree-top}

finally into the leaf-bearing twigs. Course after course continued in this way, the size decreasing gradually, and the whole forming, as seen from a distance, a magnificent domeshaped mass. Comparisons with the tree's surroundings were full of suggestiveness. The ground immediately about was densely covered with rank ferns and the acorn sprouts of one or two years' growth. Yet, where they were, it seemed but a smoothly-shaven lawn, so insignificant were they when seen with the tree; and the sproutland beyond, which would otherwise have been a wood, was absolutely insignificant. Yet, in truth, everything here was on a grand scale. The ferns were tall, and to prove it I sat upon the ground among them and so shut out all view of the great tree and its surroundings. I spent many hours seated upon different branches of this oak, and every one had features all its own. From those nearest the ground I surveyed the bird-life in the thicket beneath, and was entertained by a pair of nesting cardinal red-birds that came and went as freely as if quite alone, and whistled cheerfully morning, noon, and night. I fancied I made friends with these birds, for early one 


\section{Travels in a Tree-top}

morning the male bird came to camp, as if to inspect my nest, thinking I was not up, and he expressed his favorable opinion in most glowing terms. A pair of doves, too, had a nest in sight, and their melancholy cooing seemed out of tune here, where Nature had done her work so well. Once, at least, while I was there, the bald eagle came for a few moments, and, big bird as he is, was not conspicuous, and had not a flash of sunlight fallen upon his yellow beak and white head, I should not have been aware of his presence, as he certainly was not of mine. What I took to be a duck-hawk, a few days later, interested me much more. He was a splendid bird, and tarried but a short time. The leaves so concealed him that I was not sure, having no field-glass at the time, but do not think I was mistaken. The eagle did not appear to disturb the fish-hawk's temper in the least, but the great hawk did, and he was much excited until the bird disappeared in the steam and smoke that as a great cloud rested above Baltimore.

The birds of this retired spot may be divided into two classes, - those of the oak and of the sproutland growths about it, and 


\section{Travels in a Tree-top}

the birds of the air, principally swallows, which hung over the tree as a trembling cloud. Never were swallows more numerous, except when flocked prior to migration. In the tree and bushes were always many birds, yet often they were far from each other. This gave me an excellent idea of what a great oak really is. Birds quite out of sight and hearing of each other were resting on branches from the same trunk. Although the middle of July, there was no lack of song, and second nesting of many familiar birds is, I judge, more common in Maryland than in New Jersey. Of all the birds that came, the little green herons were the most amusing. A pair doubtless had a nest near by, or young that were not yet on the wing. They walked sedately along the level branches, as a man might pace up and down his study, buried in deep thought. I listened carefully for some expression of content, but they made no sound except when they were startled and Hew off. I was much surprised to find the beach-birds occasionally darting among the branches, and once a spotted sandpiper rested a moment near me. These birds we associate with water and the open country, 


\section{Travels in a Tree-top}

although this species is less aquatic than its fellows. They were always in sight from the door of my tent, and always an earlier bird than I. I recall now standing upon the beach long before sunrise, marking the promises of the coming day, as I interpreted them. The fish-hawks were ahead of me; so, too, the little sand-pipers. Their piping at this time was very clear and musical. It was a delightful accompaniment to the rippling water. The dear old song-sparrows were quiet, and I was very glad; but with the first flooding of the sea with sunlight they all sang out, and the Chesapeake was afar off and I in the home meadows on the Delaware. I prefer novelty when away. It is well to utterly forget, at times, that which we most prize. What boots it to stand on the hill-top, if your thoughts are forever in the lowlands? Twice, from the branches of the old oak, I saw a splendid sunset, but nothing equal to the sunrise of to-day. With many a matter of this life the beginning is better than the end. We had a superb sunset last night. The color was gorgeous, but it was plain and commonplace compared to the sunrise of to-day. Perhaps no tint was 


\section{Travels in a Tree-top}

really brighter in one case than in the other, but my mind was. The sunset was too closely linked with the death of the day; there was the idea of a grand finale before the curtain drops, and this tends to dull enthusiasm. It is not so with sunrise. It is all freshness,- a matter of birth, of beginning, of a new trial of life, - and with so happy an entrance, the exit should be one of gladness only; but there is no trace of pity in Nature. In awful certainty the night cometh.

I was not surprised at every visit to this tree to find some new form of life resting on its branches. A beautiful garter-snake had reached a low branch by climbing to it from a sapling that reached a little above it. There was no break in the highway that led to its very summit. The grass leaned upon ferns, these upon shrubs, these again upon saplings, and so the tree was reached. Any creeping thing could have climbed just eighty feet above the earth with far less danger than men encounter clambering over hills.

And not only a zoological garden was this and is every other old tree, but the oak had its botanic garden as well. When we consider that many of the branches were so wide 
and level that one could walk upon them, it is not strange that earth, dead leaves, and water should lodge in many places. Indeed, besides the two gardens I have mentioned, the oak had also an aquarium. But I cannot go into particulars. The parasitic plant-lifenot truly such, like the mistletoe-was a striking feature. Maple seeds had lodged and sprouted, and in a saucer-shaped depression where dust and water had lodged a starved hawkweed had got so far towards maturity as to be in bud.

It may appear as utter foolishness to others, but I believe that trees might in time become tiresome. Whether in leaf or bare of foliage, there is a fixedness that palls at last. We are given to looking from the tree to the world beyond; to hurrying from beneath their branches to the open country. To live in a dense forest is akin to living in a great city. There is a sense of confinement against which, sooner or later, we are sure to rebel. We long for change. The man who is perfectly satisfied has no knowledge of what satisfaction really is. Logical or not, I turned 


\section{Travels in a Tree-top}

my attention from the tree at last, and thought, What of the outlook? Directly north, in the shallow basin, hemmed in by low hills, lies the town. A cloud of smoke and steam rests over it, and barely above it reach the church-spires and tall factory chimneys, as if the place was struggling to be free, but only had its finger-tips out of the mire of the town, of which I know but little. My wonder is that so many people stay there, and, stranger still, wild life not only crowds its outskirts, but ventures into its very midst. In one town, not far away, I found the nests of seventeen species of birds, but then there was a large old cemetery and a millpond within its boundaries. Time was when through the town before me there flowed a creek, and a pretty wood flourished along its south bank. The creek is now a sewer, and an open one at that, and yet the musk-rat cannot quite make up his mind to leave it. Stranger than this was seeing recently, in a small creek discolored by a dyeing establishment, a little brown diver. How it could bring itself to swim in such filth must remain a mystery. A queer old character that had lived all his life in the country once said 


\section{Travels in a Tree-top}

of the nearest town, "It is a good place to dump what we don't want on the farm." This old fellow would always drive me out of his orchard when apples were ripe, but I liked him for the sentiment I have quoted.

I am out of town now, and what of the world in another direction? Turning to the east, I have farm after farm before me; all different, yet with a strong family likeness. This region was taken up by English Quakers about 1670 and a little later, and the houses they built were as much alike as are these people in their apparel. The second set of buildings were larger only and no less severely plain; but immediately preceding the Revolution there were some very substantial mansions erected. From my perch in the treetop I cannot see any of the houses distinctly, but locate them all by the group of Weymouth pines in front and sometimes both before and behind them. The old-time Lombardy poplar was the tree of the door-yards at first, but these, in this neighborhood, have well-nigh all died out, and the pines replace them. One farm-house is vividly pictured before me, although quite out of sight. The owner 


\section{Travels in a Tree-top}

made it a home for such birds as might choose to come, as well as for himself, and what royal days have been spent there! There was no one feature to attract instant attention as you approached the house. The trees were thrifty, the shrubbery healthy, the roses vigorous, and the flowering plants judiciously selected; but what did strike the visitor was the wealth of bird-life. For once let me catalogue what $I$ have seen in and about one door-yard and what should be about every one in the land. At the end of the house, and very near the corner of the long portico, stood a martin-box, occupied by the birds for which it was intended. In the porch, so that you could reach it with your hand, was a wren's nest, and what a strange house it had! It was a huge plaster cast of a lion's head, and between the grim teeth the bird passed and repassed continually. It promenaded at times on the lion's tongue, and sang triumphantly while perched upon an eyebrow. That wren certainly saw nothing animal-like in the plaster cast as it was, and I have wondered if it would have been equally free with a stuffed head of the animal. My many experiments witl animals, as to their recognition of ani- 
mals as pictured, have demonstrated everything, and so, I am afraid I must admit, nothing. In the woodbine on the portico were two nests, - a robin's and a chipping-sparrow's. These were close to each other, and once, when sitting in a rocking-chair, I swayed the woodbine to and fro without disturbing either bird. In the garden were a mockingbird, cat-bird, thistle-finch, song-sparrow, brown thrush, yellow-breasted chat, and redeyed vireo. In the trees I saw a great-crested fy-catcher, purple grakle, a redstart, spotted warbler, and another I failed to identify. In the field beyond the garden were red-winged blackbirds and quail, and beyond, crows, fishhawks, and turkey-buzzards were in the air ; and, as the day closed and the pleasant sights were shut out, I heard the clear call of the kill-deer plover as they passed overhead, heard it until it mingled with my dreams. "Providence Farm" is indeed well named, for the birdy blessing of Providence rests upon it; but were men more given to considering the ways and wants of wild life, we might find such pleasant places on every hand. Farms appear to be growing less farm-like. The sweet simplicity of colonial days has been 


\section{Travels in a Tree-top}

well-nigh obliterated, and nothing really better has replaced it. On the other hand, a modern "country place," where Nature is pared down until nothing but the foundationrocks remain, is, to say the least, an eyesore. There is more pleasure and profit in an Indian trail than in an asphaltum driveway.

Westward lie the meadows, and beyond them the river. Seen as a whole, they are beautiful and, like all of Nature's work, will bear close inspection. The bird's-eye view to-day was too comprehensive to be altogether enjoyable : it was bewildering. How completely such a tract epitomizes a continent! The little creek is a river; the hillock, a mountain; the brushland, a forest; the plowed tract, a desert. If this fact were not so generally forgotten we would be better content with what is immediately about us. Mere bigness is not everything. So, too, with animal life. We spend time and money to see the creatures caged in a menagerie, and never see the uncaged ones in the thicket behind the house. Every lion must roar, or we have not seen the show; a lion rampant is everything, a lion couchant, nothing. There was no visible violence in the meadows to- 


\section{Travels in a Tree-top}

day; Nature was couchant, and I was thankful. When the tempest drives over the land I want my snug harbor by the chimney-throat. The sparks can fly upward to join the storm if they will. The storms I enjoy are matters of hearsay.

Take up a ponderous government quarto of the geological survey and glance over the splendid plates of remarkable rocks, cañons, and high hills, and then look out of your window at the fields and meadow. What a contrast! Yes, a decided one, and yet if you take an open-eyed walk you will find a good deal of the same thing, but on a smaller scale. You have not thought of it before; that is all. I put this matter to a practical test not long ago, and was satisfied with the result. The last plate had been looked at and the book was closed with a sigh, and a restless youth, looking over the wide range of fields before him, was thinking of the grand mountains, strange deserts, and deep cañons pictured in the volume on his lap, and comparing such a country with the monotonous surroundings of his home.

"What a stupid place this part of the world is!" he said at last. " I wish I could go out West." 


\section{Travels in a Tree-top 35}

"Perhaps it is not so stupid as it looks," I replied. " Let's take a walk."

I knew what the book described at which the lad had been looking, and had guessed his thoughts. We started for a ramble.

"Let us follow this little brook as far as we can," I suggested, "and see what a stupid country can teach us," purposely quoting my companion's words, with a little emphasis.

Not fifty rods from beautiful old trees the collected waters, as a little brook, flowed over an outcropping of stiff clay, and here we voluntarily paused, for what one of us had seen a hundred times before was now invested with new interest. There was here not merely a smooth scooping out of a mass of the clay, to allow the waters to pass swiftly by; the least resisting veins or strata, those containing the largest percentage of sand, had yielded quickly and been deeply gullied, while elsewhere the stiff, black ridges, often almost perpendicular, still withstood the current, and, confining the waters to narrow limits, produced a series of miniature rapids and one whirlpool that recalled the headwaters of many a river.

Near by, where, when swollen by heavy 


\section{Travels in a Tree-top}

rains, the brook had filled the little valley, temporary rivulets had rushed with fury over the clay, and cut in many places deep and narrow transverse channels. From their steep sides projected many a pebble that gave us " overhanging rocks," and one small bowlder bridged a crevice in the clay, and was in use at the time as a highway for a colony of ants. Near it stood slender, conical pillars of slightly cemented sand, some six inches in height, and every one capped with a pebble of greater diameter than the apex of the supporting sand. These were indeed beautiful.

"I have never seen them before," remarked the boy.

"Very likely," I replied, " but you have crushed them under foot by the dozens." They were not to be overlooked now, though, and in them he saw perfect reproductions of wonderful "monument rocks" which he had so lately seen pictured in the ponderous government geological report.

Withdrawing to the field beyond, where a bird's-eye view of the brook's course could be obtained, we had spread out before us a miniature, in most of its essentials, of a cañon country. The various tints of the clay gave 


\section{Travels in a Tree-top}

the many-colored rocks; the different densities of the several strata resulted in deep or shallow ravines, fantastic arches, caverns, and beetling precipices. On a ridiculously small scale, you may say. True, but not too small for the eyes of him who is anxious to learn.

A few rods farther down the stream we came to a small sandy island which divided the brook and made a pleasant variety after a monotonous course through nearly level fields. A handful of the sand told the story. Here, meeting with so slight an obstruetion as a projecting root, the sandy clays from above had been deposited in part, and year after year, as the island grew, the crowded waters had encroached upon the yielding banks on either side, and made here quite a wide and shallow stream. Small as it was, this little sand-bar had the characteristic features of all islands. The water rippled along its sides and gave it a pretty beach of sloping, snow-white sand, while scarcely more than half a foot inland the seeds of many plants had sprouted, and along the central ridge or backbone the sod was thick set, and several acorns, a year before, had sprouted through it. We found snails, spiders, and insects 
abundant, and faint footprints showed that it was not overlooked by the pretty teetering sand-piper.

Now came a total change. Abruptly turning from its former straightforward course, the brook entered a low-lying swamp, crowded to the utmost with dense growths of tangled vines and stunted trees. The water was no longer sparkling and colorless, but amber-tinted, and in many a shallow pool looked more like ink. Life here appeared in many forms. Small mud-minnows, turtles, and snakes were found in the gloomy, weedhidden pools, and numberless insects crowded the rank growths above as well as the waters beneath. The mutual dependence of vegetation and animal life was here very striking. Previously we had found comparatively little either in the brook or about it, but now our eyes were gladdened not only with what I have mentioned, but birds, too, were in abundance.

Bent upon freeing my native county from the charge of stupidity, I led the way through this " dismal swamp." It was no easy task. Nowhere were we sure of our footing, and it required constant leaping from root to root 


\section{Travels in a Tree-top}

of the larger trees. There was at times no well-defined channel, and often we could hear the gurgling waters hurrying beneath our feet, yet catch no glimpse of them.

Here, too, other springs welled to the surface, and the augmented volume of waters finally left the swamp a stream of considerable size, which, after a tortuous course through many fields, entered a deep and narrow ravine. After untold centuries the brook has worn away the surface soil over which it originally flowed, then the gravel beneath, and so down to the clay, thirty feet below. Upon this now rest the bowlders and such coarser material as the waters could not transport.

Clinging to the trees growing upon the sides of the ravine, we closely followed the course of the troubled, bubbling, foamy waters, stopping ever and anon to look at the exposed sections of sand and gravel here shown in curious alternate layers. The meaning of the word "deposits," so frequently met with in descriptive geology, was made plain, and when we noticed of how mixed a character was the coarse gravel, it was easy to comprehend what had been read of that most interesting phase of the 


\section{Travels in a Tree-top}

world's past history, the glacial epoch, or great ice age. The gravel was no longer an unsuggestive accumulation of pebbles, but associated rolled and water-worn fragments of a hundred different rocks that by the mighty forces of ice and water had been brought to their present position from regions far away.

The ravine ended at the meadows, through which the waters passed with unobstructed flow "to join the brimming river." As we stood upon the bank of the mighty stream I remarked, "This is a stupid country, perhaps, but it has some merits." I think the boy thought so, too.

The meadows are such a comprehensive place that no one knows where to begin, if the attempt is made to enumerate their features. There is such a blending of dry land and wet, open and thicket-grown, hedge and brook and scattered trees, that it is bewildering if you do not choose some one point for close inspection. From the tree-top I overlook it all, and try in vain to determine whether the azure strip of flowering iris or the flaunting crimson of the Turk's cap lilies 


\section{Travels in a Tree-top}

is the prettier. Beyond, in damper soil, the glistening yellow of the sunflowers is really too bright to be beautiful; but not so where the water is hidden by the huge circular leaves of the lotus. They are majestic as well as pretty, and the sparse bloom, yellow and rosy pink, is even the more conspicuous by reason of its background. How well the birds know the wild meadow tracts! They have not forsaken my tree and its surroundings, but for one here I see a dozen there. Mere inky specks, as seen from my point of view, but I know them as marsh-wrens and swamp-sparrows, kingbirds and red-wings, that will soon form those enormous flocks that add so marked a feature to the autumn landscape. It needs no field-glass to mark down the passing herons that, coming from the river-shore, take a noontide rest in the overgrown marsh.

I had once, on the very spot at which I was now looking, an unlooked-for adventure. For want of something better to do, I pushed my way into the weedy marsh until I reached a prostrate tree-trunk that during the last freshet had stranded there. It was a wild place. The tall rose-mallow and wavy cat- 


\section{Travels in a Tree-top}

tail were far above my head, and every trace of civilization was effectually shut out. It was as much a wilderness as any jungle in the tropics. Nor was I alone. Not a minute elapsed before a faint squeak told me that there were meadow-mice in the hollow log on which I sat. Then the rank grass moved and a least bittern came into view and as quickly disappeared. I heard continually the cackle of the king-rail, and the liquid twittering of the marsh-wrens was a delight. The huge globular nests of these birds were everywhere about me; but the birds did not think of me as having any evil designs upon them, so they came and went as freely as if alone. This is bird-viewing that one too seldom enjoys nowadays. Often, and very suddenly, all sound ceased and every bird disappeared. I did not recognize the cause at first, but was enlightened a moment later. A large bird passed over, and its very shadow frightened the little marsh-dwellers. If not, the shadow and fright were a coincidence several times that morning. The day, for me, ended with the unusual chance of a close encounter with a great blue heron. I saw the bird hover for a moment directly overhead, and then, let- 


\section{'Travels in a Tree-top}

ting its legs drop, it descended with lead-like rapidity. I leaned backward to avoid it, and could have touched the bird when it reached the ground, it was so near. I shall never know which was the more astonished. Certainly, had it chosen, it could have stabbed me through and through.

I was glad to be again on drier land and in open country. There had been adventure enough; and yet, as seen from a distance, this bit of marsh was but weeds and water.

Southward there stands the remnant of a forest : second-and third-growth woodland usually; for trees of really great age are now generally alone. I can see from where I sit three primeval beeches that are known to be over two centuries old, and not far away towered one giant tulip-tree that since the country's earliest settlement had stood like a faithful sentinel, guarding the south bank of a nameless spring brook. Ever a thing of beauty, it shone with added splendor at night, when the rising full moon rested in its arms, as if weary at the very outset of her journey. My grandfather told me that in his boyhood it was known as the "Indian tree," because a basket-maker and his squaw had a wigwam 


\section{Travels in a Tree-top}

there. That was a century ago, and often, of late years, I have hunted on the spot for some trace of these redskins, but found nothing, although all about, in every field, were old Indian relics, even their cherished tobacco-pipes. Small, recent growths of timber, even where they have succeeded an ancient forest, are not, as a rule, attractive. Their newness is too evident, and, except for a few passing birds, they are not apt to harbor much wild life. As I look at the mingled foliage of oaks and elms, beeches, hickories, and wild cherry, I give little heed to that before me and recall forests worthy of the name, doing precisely what I have declared unwise. A naturalist could find more material in these few acres of woodland than he could "work up" in a lifetime. I have underrated them. From the little thicket of blackberry vines I see a rabbit slowly loping, as if in search of food. It is a full-grown fellow, and suggests the round of the traps in late autumn and the woods in winter.

I never knew a boy brought up in the country who was not at one time an enthusiastic trapper. Just as mankind in the in- 


\section{Travels in a Tree-top}

fancy of the world were forced to pit their energy and skill against the cunning of the animals needed for food or of such that by reason of their fierceness endangered human life, so the country boy of to-day puts his intelligence to work to circumvent the superiority of such animal life as by fleetness of foot or stroke of wing can avoid the pursuer. It is a question largely of brain against anatomical structure. No Indian, even, ever outran a deer, nor savage anywhere by mere bodily exertion stopped the flight of a bird. Men were all sportsmen, in a sense, when sport, as we call it, was necessary to human existence. As centuries rolled by, such animals and birds as came in daily contact with man necessarily had their sleepy wits aroused, and now it is a case of cunning against cunning. We are all familiar with such phrases as "wild as a hawk" and "shy as a deer." In the morning of man's career on earth there were no such words as "shy" and "wild." They came into use, as words are constantly coming into our language, because circumstances make them a necessity; and as men were trappers before they were traders or tillers of the field, so the words 


\section{Travels in a Tree-top}

are old, and while animal life lasts they will be retained.

Nowadays we generally outgrow this love of trapping, or it remains in the love of sport with gun or rod. But, old Izaak Walton and Frank Forrester to the contrary notwithstanding, I hold that nothing in fishing or shooting has that freshness, that thrilling excitement, that close touch with nature, that clings to our early days, when, in autumn and winter, we went the round of the traps. How through the long night we had visions of the rabbit cautiously approaching the box-trap on the edge of the swamp! How clearly we saw in the corner of the weedy old wormfence the stupid opossum bungling along, and awoke with a start as the clumsy creature sprang the trap from the outside! I pity the boy who has not had such a distressing dream.

No boy ever turned out before sunrise with a smiling countenance to milk or help in any way with farm work; but how different when it was a matter of the traps he had set the night before! The anticipation of success is an all-sufficient incentive, and neither bitter cold nor driving storm deters him. Of a winter dawn much might be said. No boy 


\section{Travels in a Tree-top}

ever was abroad so early that the squirrels were not before him, and in the fading light of the stars he will hear the crows cawing and the blue-jays chattering in the woods. To the naturalist, of course, such time of day is full of suggestiveness; but the general belief that it is a proper time to sleep will never be given up. Indeed, judging others by myself, as the boy gets well on in his teens there is a growing disposition to let the traps go until broad daylight and even until after breakfast. This is unfortunate in two ways: there is a likelihood of seeing animal life in the full flush of activity in the pre-sunlit hours that is unknown as the day advances; the night-prowlers are all gone to their dens, and the birds that roost in colonies have dispersed for the day. One seldom overtakes a raccoon or a weasel at or near noontide, and in the woods where a thousand robins have roosted there may now not be one. Then, again, your visit to the traps may be anticipated if you are too deliberate in starting on your rounds. This is an experience that no boy of spirit can calmly undergo, and no wonder. The rude box-trap was not easy to make, considering the usual condition of tools upon a 


\section{Travels in a Tree-top}

farm. The hunt for likely places whereat to set it had been real labor. The long tramp in the gloaming when tired out from a day at school; the early tramp, before sunrise perhaps, for he must be on time at school that morning,-all this is to be considered; but if success crowns the effort, all is well. On the other hand, to find that some rascal has been ahead of you and your labor has gone for nothing__ I never knew a boy to be a saint at such a time.

I can recall a well-marked rabbit-path I once found, half a mile from home, and with great secrecy carried one of my traps to the place. It was on the next farm, and so I had to be more than usually careful. Nothing could be done in daylight for fear the boys living on that farm would find me out, and this sort of poaching was not tolerated. At first I was successful, catching two fine rabbits, and then, alas! was so elated that, boylike, I said too much. Some one must have tracked me, for I caught no more, although it was evident that the trap had been disturbed. Straightway I suspected treachery, and prepared for revenge.

Now, auntie had a fur tippet, or "boa," 


\section{Travels in a Tree-top}

as she called it, which was just six feet long. The moths one summer had ruined it, and for some time it had been lying around uncared for and a plaything for the younger children. This I appropriated, and fastened to one end of it a rabbit's head, with the ears wired up and with huge painted marbles bulging from the sockets for eyes. It was a startling if not life-like creature.

Armed with this, I started after dark to the trap, and soon had all in readiness for my victim. I coiled the "boa" into the rear of the box and placed the head near the opening of the trap. The " figure-of-four" triggers were laid outside in such a way as to suggest that the trap had been sprung by an animal. Then I went home.

The next morning I went to school without visiting the spot, fearing I might meet with the supposed offender. All day long I wondered. No boy had any marvellous tale to tell and no one looked at all guilty. There soon came over me a feeling that perhaps I had played a trick upon myself, and by sundown I was rather reluctant to determine if anything had happened; but go I did. The trap had evidently been disturbed. The c $d$ 


\section{Travels in a Tree-top}

"boa" with the rabbit's head was lying at full length outside and the bushes were broken as if a bull had rushed through them. But who or what had been there?

Two days of most distressing doubt passed, and then came Saturday. I was ill at ease and took no pleasure in my holiday; but about noon our neighbor came over, and I heard him tell grandfather how, on Fifth-day, while the family were at breakfast, Bill, the bound boy, came rushing into the room and exclaimed, excitedly, "Something from the menagerie's broke loose and got in the rabbit-trap !"

I had had my revenge.

A wood, to be at its best, should be located on the shore of a lake or river, or, perhaps better still, a river should run through it. Here are my impressions of such a wood, from my note-book of 1892, under date of May 1:

Nothing could have been more fitting than to take a May-day outing at such a place. The swift current of the Great Egg Harbor River rolled resistlessly along, its waters black as night, save where, over the pebbly shallows, it gleamed like polished amber. The wind that swayed the tall crowns of the tow- 


\section{Travels in a Tree-top}

ering pines made fitting music, according well with the rippling laugh of the fretted river, while heard above all were the joyous songs of innumerable warblers.

We had placed our boat upon a wagon six miles below our point of departure, and partly realized on our way what this pine region really was. The cedar swamp, the oak openings, the arbutus that gave color to the narrow wagon-track, the absence of man's interference,-all tended to give us the full significance of that most suggestive word, wilderness. We needed but to catch a glimpse of an Indian to see this part of creation precisely as it was in pre-Columbian days. I sat for some time in the boat before taking up the anchor. This was but the entrance, $I$ was told, to spots more beautiful, but it was hard to believe. Here was a river hidden in a forest, and what more could one wish? The warblers well knew that May-day had come again, and every one of the mighty host greeted the brilliant sunshine. There seemed literally to be hundreds of them. Flashing like gems were redstarts, light as swallows upon the wing. Bright-spotted warblers, and others sombre gray, laughed 


\section{$5^{2}$}

\section{Travels in a Tree-top}

as they tarried on the trembling twigs; then, mounting into the sunlight, sang loudly as they flew, or darted into gloomy nooks so hidden that not even a sunbeam could follow them.

The river with its attendant birds could not claim all the merit; the land was no less beautiful. The oaks were not yet in leaf, but there was no lack of green. The holly's foliage was bright as May, the polished leaves of the tea-berry shone as a midsummer growth, the ink-berry had defied the winter's storms, and the maples glowed as a great ruddy flame. Really distinct as was every object, yet, as a whole, the outlook was dreary, hazy, half obscure, as we looked directly into the wood, where the drooping moss festooned the branches of the smaller oaks.

No voyager ever set forth from so fair a port.

My companion knew the route, and with an oar he took his place astern to guide the boat safely down the swift stream. It was all right as it proved, but at times I forgot that I had come to see the forest. Instead, an element of doubt as to the guide's ability came painfully to the front. With devilish 


\section{Travels in a Tree-top}

malignancy, as I thought, trees had prostrated themselves and rested just beneath the water's surface, or stood up, with outreached arms, as if defying us. How we passed many a crook and turn I cannot now remember. I was too much occupied with desperately clutching at anything within reach to notice the "when" or "how," but there still remains the delicious sensation of suddenly shooting into smooth water and feelingbrave as a lion.

For several miles on either side of the stream we had a typical mixed forest. The willow-oak predominated at times, and the delicate foliage, so unlike other oaks, was very beautiful. The leaves appeared translucent in the bright sunlight, fairly sparkled, and once made a splendid background to scarlet tanagers that flashed through them. In this long reach of dense woods there were fewer birds than at our starting-point, or perhaps they held back as we passed. But other life was not wanting. From many a projecting stump there slid many a turtle into the dark waters, and a mink or musk-rat crossed our bow. Careful search would no doubt have revealed numerous creatures, for here was a safe retreat for all the $5^{*}$ 


\section{Travels in a Tree-top}

fauna of the State. The deer are not yet quite gone, possibly a few bears remain. Certainly the raccoon and otter must be abundant. I was constantly on the lookout for minks, for the river abounds in fish. This animal is sometimes mistaken for a huge snake, as it rises several inches above the water at times, and has then a rather startling appearance. An old fisherman on Chesapeake Bay told me that he had seen a mink with a huge eel in its mouth come to the surface, and then the wriggling fish and long, lithe body of the mink together looked like two serpents fighting. I can readily imagine it. Birches, liquidambars, and pines in clusters would next command attention, and usually there was a dense undergrowth. Holding the boat, at times, we could hear the water rushing through the roots of this tangled mass, and found that what we had supposed was firm land afforded no certain footing, and a bluff of firm earth was very welcome when we thought of landing for a hasty lunch. This firm earth did indeed support us, but in reality it was the most unstable of shifting sands, being held in place by reindeer-moss, partridge-berry, and other pine-barren growths. 


\section{Travels in a Tree-top 55}

Nothing was in sight but the scrubby pines, and we had to be very careful that our fire did not get among the "needles" and dash through the woods. I found here absolutely no birds. They seem all to prefer the tracts covered by deciduous trees; but insect-feeders could have flourished here. The steam of our dinner-pot brought more substantial forms than mosquitoes, one house-fly being determined to share my Frankfurter and successfully defying all attempts at capture.

Again afloat, we soon came to the mouth of an inflowing stream called Dead River, said to be very deep. This point was perhaps the wildest of all. The open water here was very wide, and a forest of projecting stumps of various heights showed plainly that we were on the edge of an area of drowned land. In the distance was an unbroken background of pines, which now looked black. At wide intervals could be seen huge pines that had escaped the charcoal-burner or lumberman. The stems and lower branches were, of course, concealed, but in the hazy atmosphere the tops were as floating islands of darkest green, standing boldly out against the pearly sky behind them. 


\section{Travels in a Tree-top}

Here, at the mouth of Dead River, we beheld a pretty sight. A wood-duck with her brood rushed over the water in a most lively manner, flecking the black expanse with patches of white foam. Such incidents add much to such a journey. An empty forest is as forbidding as an empty house.

In the coves there were changes from the surrounding scenery that were not to be overlooked. A rank growth of golden-club resting on the dark waters was very striking. The picture was such as we see on a Claude Lorrain glass. Near by fresh sphagnum in a shallow pool was bronze and green : a place for frogs to squat unseen, but I could find none. How often this happens! At the very places where we think animal life will be in abundance we can find no trace of it. Then, looking up, we see but trees. No break in the line that hems us in. Trees old and young, trees living and dead, great and small; nothing but trees.

The wind freshened as the day grew old, and doubly troubled were the waters. There was no rest for them now, even in sheltered nooks, and it was only by sturdy strokes of the oars that we made headway at all. There 


\section{Travels in a Tree-top}

was no perceptible current to bear us along as before. The waves dashing against the bare trunks of trees long dead and now bent by the wind added much to the wild scene. Novel as it all was, I could not quite enjoy it. It was something to be contemplated from the shore, I thought. I know I was laughed at, but the many "blind" stumps, or those just beneath the surface, of which my companion spoke so unconcernedly came too prominently to mind when I least expected them, and added much significance to the fact that I cannot swim.

As we neared home the scene abruptly changed, and the river was lost in a wide expanse that might be called a lake if the fact was not so evident that it is a mill-pond. This, however, did not detract from the beauty of the surroundings, and before our final landing we drew up to a bold bit of shore and searched, while it was yet day, for pyxie. There was an abundance of blooming andromeda, too, and arbutus, with clubmoss of richest green. I almost placed my hand on a centipede that glowed like an emerald. It was resting on ruddy sphagnum, and made a splendid picture. I could not 


\section{$5^{8}$}

Travels in a Tree-top

capture the creature. An attempt to do so on my part was followed by its disappearance with a suddenness that could be likened only to the flashes of light that played upon its back. Here I heard many frogs, but could find none. The rattle and peep were not like the voices of those in the meadows at home, and I wondered about Cope's new tiger-frog and the little green hyla that is so rare here in Jersey. Possibly I heard them both; probably not.

We returned to prosy life when the boat was lifted over the dam, and the incidents were few and commonplace in the short drift that carried us to an old wharf, a relic of the last century.

What a difference between such a forest and a few hundred oaks and ashes at home! and yet these are far better than treeless fields. It is these few trees that hold many of our migratory birds, and through them, in spring, troop the north-bound warblers. In the gloaming a small trakt of woodland widens out, and, seeing no open country beyond, what does it matter, if we walk in a circle, whether it be one acre or one thousand? 


\section{Travels in a Tree-top}

There is good philosophy in "Small favors thankfully received." Here in this little wood are beautiful white-footed mice, a shy, nocturnal jerboa, Alying-squirrels, and, if I mistake not, a whole family of opossums. Here, until autumn, are wood-robins that never weary us by overmuch singing, and cat-birds, chewinks, and the rose-breasted grosbeak. 1 do not complain, but as the summer passes I regret that these birds have their appointed time and will soon be gone. Why so soon? I often wonder, for their haunts do not lose their loveliness for weeks after they have disappeared.

No wall of green above, about,

They silently steal away;

With but a carpet of withered leaves,

The minstrel will not stay.

But the spot is no "banquet-hall deserted," for all that; the departure of the summer birds is but to make way for those who have gladdened Canadian woods for many weeks. The purple finch will soon be here, and treesparrows in great companies, and the gentle white-throat; and these, with our stately cardinal for a leader, will hold forth melodi- 


\section{Travels in a Tree-top}

ously, though the north winds blow and the angry east wind brings the snow upon its wings.

In the smile of winter sunshine there will be enacted another drama, but now it is comedy rather than tragedy. There are no conflicting interests now, no serious quarrels, no carking cares-the world is really in good humor and our days of early darkness are misunderstood.

Let him who doubts-and there are but few who do not-turn from the worn lines of travel, go well out of the beaten path, and find, in the way-side nooks his neighbors have neglected, most excellent company : birds of brave heart that can sing in the teeth of a storm; and many a creature, wrapped in his furry coat, laughs at the earnest efforts of winter to keep him from his outings.

Did I dare sit in this same oak when the leaves have fallen, I should have strange tales to tell, - tales so strange that the summertide would be commonplace in comparison. 


\section{A HUNT FOR THE PYXIE}

JO storm raged to defeat a long-cherished I plan, and we must laugh at threatening clouds or miss many an outing. In dreams the pyxie had been blooming for weeks, and to prove that not all dreams go by contraries, I started on a flower-hunt. This is not always so tame and adventureless a matter as one might think. There are wood-blooms that scorn even a trace of man's interference, and the pyxie is one of them. Nature alone can provide its wants, and only where Nature holds undisputed sway can it be found. To find this beautiful flower we must plunge into the wilderness.

It was a long tramp, but never wanting a purpose for every step taken. Each turn in the path offered something new, and if ever for a moment a trace of weariness was felt, it was because even to our hungry eyes 


\section{A Hunt for the Pyxie}

the wilderness was overfull. Bewildering multitudes are more to be feared than possible dangers. There is no escape from the former. Not a tree or bush, not a bird or blossom, but to-day offered excellent reason why with them we should spend our time; and how often they all spoke at once!

Except the ceaseless rattle of small frogs, there was no sound, for that sad sighing of the tall pines seems but the rhythmic breathing of silence; or, passing from the wet grounds to the higher, drier, and more barren tracts, we heard only the crisp crackling of the reindeer-moss we crushed at every step. Although

"It is the bright day that brings forth the adder, And that craves wary walking,"

we gave no thought to possible danger,-for rattlesnakes are still to be found. Not even when we stooped to pick the bright berries of winter-green did we think of a coiled serpent buried in dead leaves; and what opportunity for murder the serpent had as we buried our faces in pillows of pink and pearly arbutus!

At last we reached South River (in South- 


\section{A Hunt for the Pyxie $6_{3}$}

ern New Jersey), and just here was no place to tarry, unless to court melancholy. It was not required that my companion should enumerate the reasons why the one-time farm along the river-bank had been abandoned. A glance at the surrounding fields told the whole story. There was, indeed, barrenness,-and very different, this, from what obtains in localities near by to which the same term is applied. In the so-called pine barrens there is a luxuriant vegetation; but here about the deserted house and out-building there was nothing but glistening sand, moss, and those pallid grasses that suggest death rather than life, however feeble. And how widely different is it to be surrounded by ruin wrought by man, and to be in a forest where man has never been! Could I not have turned my back upon the scene and looked out only upon the river, the day's pleasure would have vanished. But we were soon away, and a naturalist's paradise was spread before us. What constitutes such a place? Not necessarily one where man has never been : it will suffice if Nature has withstood his interference; and this is true of these pine barrens, this weedy wilderness, this 


\section{A Hunt for the Pyxie}

silent battle-field where the struggle for existence never ceases, and yet, as we see it, peaceful as the fleecy clouds that fleck an April sky.

Though the wind that swept the wide reach of waters close at hand still smacked of wintry weather, there was a welcome warmth on shore. The oaks even hinted of the coming leaf. Their buds were so far swollen that the sharp outlines of bare twigs against the sky were rounded off. The ruddy stems of the blueberry bushes gave to the river-bank a fire-like glow, and yet more telling was the wealth of bright golden glow where the tall Indian grass waved in all its glory. The repellent desolation of midwinter, so common to our cold-soil upland fields, was wholly wanting here; for, while nothing strongly suggested life as we think of it, even in early spring, yet nothing recalled death, the familiar feature of a midwinter landscape.

The scattered cedars were not gloomy today. Their green-black foliage stood out in bold relief, a fitting background to the picture of Spring's promises. That the sea was not far off is evident, for even here, a dozen miles 


\section{A Hunt for the Pyxie 65}

from the ocean, many of these trees were bent and squatty at the top, as are all those that face the fury of storms along the coast. Every one harbored north-bound migrating birds; restless, warbling kinglets principally. No other tree seemed to attract these pretty birds, many a flock passing by scores of oaks to the next cedar in their line of march. The clustered pines were not similarly favored, not a bird of any kind appearing about them, and life of all kinds was wholly absent in the long aisles between their stately trunks. Our path led us through one great grove where every tree grew straight and tall as a ship's mast. The light that filled this wood was strangely beautiful. Nothing stood out distinetly. To have passed here in the gloaming would have tried weak nerves. Even in the glare of noonday my imagination was abnormally active, every stunted shrub and prostrate log assuming some startling shape. Think of such a place after sunset! Let an owl whoop in your ears when hedged in by thick-set trees! Philosophize as one will in daylight, it goes for little now, and the days of Indians, cougars, and all ill-natured beasts come trooping back. This distrust of dark- 


\section{A Hunt for the Pyxie}

ness is not mere cowardice, and I would accept no one's statement that he is wholly free of it. Every sound becomes unduly significant when we are alone in a wilderness; often unpleasantly so, even during the day, and

" in the night, imagining some fear,

How easy is a bush supposed a bear!"

Out of the pines and into the oak woods : the change was very abrupt, and as complete as possible. Every feature of the surroundings was bathed in light now, and the emergence from the pine forest's gloom restored our spirits. We are ever craving variety, and there was positive beauty in every stunted oak's ugliness, and from them we needed but to turn our heads to see thrifty magnolias near the river-bank. These have no special enemy, now that the beavers are gone, and thrive in the black mud by the water's edge; better, by far, than the gum-trees near them, for these were heavy laden with pallid mistletoe,-to me a most repugnant growth.

We reached open country at last, and here were birds without number. How quickly all else fades at such a time! The whole 


\section{A Hunt for the Pyxie 67}

valley trembled with the ringing whistle of a thousand red-wings. A few swallows-the first of their kind to return-darted over the wide waters and rested on projecting branches of trees that floods had stranded on the islands. The sprightly kill-deers ran with such dainty steps over the sand that I could not find their footprints. They, too, were pioneer birds, but none the less light-hearted because alone. They sang with all their last year's earnestness, scattering music among the marshes where frogs were now holding high carnival. They were very tame, at least so far as we were concerned, but a little in doubt as to what a stray hawk might be about. But they left us only to make room for others, and whether we looked riverward or landward mattered not: it was birds, birds, birds! Here a hundred sparrows in an oak, there a troop of snow-birds in the bushes, a whistling titmouse sounding his piercing notes, the plaintive bluebird floating overhead, the laugh of the loon at the bend of the river, and buzzards searching for stranded herring where the seine had been drawn.

A flock of herons, too, passed overhead, 


\section{A Hunt for the Pyxie}

and, had they not seen us, might have stopped here on the river-shore. What an addition to a landscape! and yet now so seldom seen. No birds can be more harmless than they, yet not even the hawks are subject to greater persecution. Not long since these birds were abundant, and a "heronry" was one of the "sights" of many a neighborhood; but people now scarcely know what a "heronry" is. The very word suggests how rapidly our large birds are disappearing, and their roosting-places, where hundreds gathered and nested, too, in season, are matters of " ancient history." In fear and trembling, the herons that linger about our watercourses singly seek secluded trees wherein to rest, and, I fear, even then sleep with one eye open. A fancy, on the part of women, for heron plumes has wrought a deal of mischief.

But where is the pyxie? We knew it must be near at hand, but why make haste to find it? All else was so beautiful here, why not wait even until another day? The river-bank was itself a study. At the top, sand of snowy whiteness; then a ribbon of clay over which water trickled carrying iron in solution, that was slowly cementing a sand 


\section{A Hunt for the Pyxie}

stratum beneath, where every degree of density could be found, from solid rock to a paste-like mass that we took pleasure in moulding into fantastic shapes, thereby renewing our dirt-pie days.

A little later in the year, this bluff, now streaked and spotted, will be green with the broad-leaved sundews, curious carnivorous plants that here take the place of grasses. There is a filiform sundew that grows near by, where the ground is high, if not dry; but it, too, waits for warmer days. Not so the pyxie. Almost at first glance, as we left the bluff, we saw it, sparkling white, nestled among the gray mats of reindeer-moss, or fringed by shining winter-green still laden with its crimson fruit.

Here the earth was strangely carpeted. Sphagnum, beautiful by reason of rich color, gray-green moss, and the object of our long tramp,-pyxie. No botany does it justice, passing it by with the mere mention of its barbarous name, Pyxidantbera barbulata. It might be thought the meanest of all weeds, but is, in truth, the chiefest glory of this wonderful region.

Is it strange we regretted that Time would 


\section{A Hunt for the Pyxie}

not slacken his pace? I know not where else, in these northern regions, so much is to be seen, and so soon. Spring, elsewhere, is the round year's strangest child, often too forward, and too often backward; but her accomplishments here and now are beyond criticism. Such perfect work, and yet she is not out of her teens. The day was April 1. 


\section{THE COMING OF THE BIRDS}

THE moon in April is an important fac1 tor in the progress of that event-the coming of the birds-which makes every spring memorable. While not disposed to wait upon it too long, still, there is little doubt but that the birds that have been wintering afar south travel very largely by its light, and when it happens that the moon fulls between the middle and the twenty-fifth of the month, the flights of thrushes, orioles, wrens, and other migrants reach us a week earlier than when the nights are dark during the same period. Temperature, storms, and general backwardness of the season do not seem to have a like importance in bird economy.

Of course, by the coming of the birds I do not refer to the pioneers that are in advance of every company. Indeed, I have seldom announced the first of the season, but 


\section{The Coming of the Birds}

I have been met by the man who was at least one day ahead of me; so firstlings are not favorites.

There is every year the one memorable morning when we can say, in broad terms, "The birds are here." When the oriole whistles from the tallest tree in the lawn; when the wren chatters from the portal of his old-time home; when the indigo-finch sings in the weedy pasture; when lisping warblers throng every tree and shrub; while over all, high in air, the twittering swallows dart in ecstasy ; and at last, the day-long concert over, whippoorwills in the woods pipe their monotonous refrain. The Indians were right: when there came such days as this, they had no further fear of frost, and we need have but little. Our climate certainly has changed slightly since their time, but we have in such a bird-full day an assurance that the clinging finger-tips of Winter have at last relaxed and his hold upon our fields and forests is lost.

A word again of the advance guard. The brown thrush came on the seventeenth of the month (April, 1892), when there were no leafy thickets and the maples only were in 


\section{The Coming of the Birds 73}

bloom. What a glorious herald he proved! and so he always proves. Before the sun was up I heard him in my dreams, and later the fancy proved a fact. Perched at the very top of an old walnut-tree, where the wintry world was spread before him, he sang that song peculiarly his own.

No hint of blushing roses on the hill,

The buds are sleeping yet upon the plain, The blight of dreary winter clingeth still,

The forest weeps where falls the chilly rain.

Scarce hopeful leaf-buds shrink-death's solemn hush

Rests on the field, the meadow brook along, Till bieaks the day, $O$ happy day! the thrush

Foretells the coming summer in a song.

Two days later it was almost summer, and tripping along the river's pebbly beach were spotted sand-pipers. They were ahead of time this year, I thought, but none the less happy because the trees were bare and the water cold; but, stranger still, in the sheltered coves of the mill-pond, that now reflected the gold of the spice-wood and the crimson of the overhanging maples, there were warblers, merry as in midsummer, and a pair, at least, of small thrushes. A bittern, too, stood 


\section{The Coming of the Birds}

in the weedy marsh. There they had gathered on that sunny, summery day, as if warm weather was an established fact; but how different the next morning, when a cold north-east storm prevailed! How well it showed that one such sunny day does not make a season! How clearly it proved that birds have no prophetic insight! They were caught and suffered and disappeared. Did they fly above the clouds and go to some distant point, free of chilling rain, or did they hide in the cedar swamps? This problem I did not essay to solve. In the few cedars along the river-shore I found nothing but winter residents, but I made no careful search. A few days later and spring-like conditions again prevailed and every day some new bird was seen, but not until May I could we say, "The birds have come."

These uncertain April days are not disappointing. We are not warranted in expecting much of them, and whatsoever we do meet with is just so much more than we had reason to look for, - an added bit of good luck that increases our love for the year's fourth month; but if no migrant came, there is little likelihood that the pastures and river- 


\section{The Coming of the Birds 75}

shore would be silent. There never was an April that had not its full complement of robins and blithe meadow-larks, of glorious crested tits and gay cardinals, of restless red-wings and stately grakles, and these are quite equal to driving dull care away, and keeping it away, if the migrants did not come at all. Even in March, and early in the month, we often have a foretaste of abundant bird-life; an intimation of what a few weeks will bring us. A bright March morning in 1893 was an instance of this. I walked for miles along the river-bank with a learned German who was enthusiastic about everything but what interested me. This may not seem to be a promising outlook, but we undertook to convert each other. I was to give up my frivolity, he determined. My effort was to get his dry-as-dust whimsies out of him. The great ice-gorge of the past winter was now a torrent of muddy waters and huge cakes of crystal that rushed and roared not only through the river's channel, but over half the meadow-land that bordered it. It was, I admit, an excellent opportunity to study the effects of such occurrences, for to them is due the shaping of the valley, 


\section{The Coming of the Birds}

and gravel transportation, and all that; but then there was the effect of light and shade upon the wonderful scene, and beauty like this crowded out my taste for geology. The sky was darkly blue, flecked with great masses of snow white-cloud that drifted between the sun and earth, casting shadows that blackened the ice and brought winter back again; but a moment later a flood of sunshine as promptly changed all, and the bluebirds hinted of spring. Then, too, the gulls and crows screamed above the roar and crunching of the ice as it struck the scattered trees, while in every sheltered nook was a full complement of song-sparrows. Why any one should bother about geology at such a time I could not see; but my companion was intent upon problems of the ice age, and continually remarked, "Now, if" or " Don't you see?" but I always cut him short with "See that crow ?" or "Hear that sparrow ?" No, he had not seen or heard the birds, and neither had I his particular impressions. At last the sunshine broke upon him, and he laughed aloud when he saw the crows trying to steal a ride on ice-rafts that continually upset. I was hopeful now, and he 


\section{The Coming of the Birds 77}

soon heard the birds that sang, and whistled after a long line of kill-deer plover that hurried by, every one calling to his fellows. It was something to know that the coming of the birds can rouse a German out of his everlasting problems. He had more to say of the springtide so near at hand than had I, and, nosing over the ground, found nine vigorous plants in active growth, and spoke so learnedly of Cyperus, Galium, Allium, and Saponaria that I as glibly thought, in jealous mood, "Confound him!" for now he was taking possession of my province and showing me my littleness; but then I had dragged him out of his problems.

The truth is, I was in something like despair when we started out, for I feared a lecture on physical geography, and, indeed, did not quite escape; but the bitter was well mixed with the sweet, and he in time listened with all my ardor to the birds that braved the boisterous wind and were not afraid of a river wilder than they had ever seen before. The day proved to be of more significance than as regards mere glacial geology. It was a foretaste of what was coming in April. I drew a glowing picture of what our April meant, $7^{*}$ 


\section{The Coming of the Birds}

and pictured a peaceful river and violets and meadow blossoms as bright as they were fragrant. My learned friend smiled, then grew enthusiastic; must come again to see the birds as they arrived, and-must I say it ?-spoke of beer. Alas! it was Sunday.

There are two reasons why April birds are particularly attractive. One is, there are fewer of them, and again, there is practically no foliage to conceal them. Better one bird in full view than a dozen half hidden. Their songs, too, have a flavor of novelty, and ring so assuringly through the leafless woods. The ear forever bends graciously to promises, even though we know they will be broken; but birds, unlike men, are not given to lying. When they promise May flowers and green leaves they mean it, and, so far as history records, there has never been a May without them, not even the cold May of 1816 , when there was ice and snow. But aside from their singing, April birds offer the opportunity of studying their manners, which is better to know than the number of their tail-feathers or the color of their eggs. The brown thrush that sings so glibly from the bare branch of a lonely tree shows now, by his 


\section{The Coming of the Birds 79}

way of holding himself and pointing his tail, that he is closely akin to the little wrens and their big cousin, the Carolina mocker, so called, which does not mock at all. Of all our April birds, I believe I love best the chewink, or swamp-robin. To be sure, he is no more a feature of April than of June, and many are here all winter; but when he scatters the dead leaves and whistles his bi-syllabic refrain with a vim that rouses an echo, or mounts a bush and sings his few notes of real music, we forget that summer is only on the way, but not yet here. Of all our birds, I always fancied this one was most set in his singing, as he surely is in his ways; but Cheney tells us that " this bird, like many others, can extemporize finely when the spirit moves him. For several successive days one season a chewink gave me very interesting exhibitions of the kind. He fairly revelled in the new song, repeating it times without number. Whether he stole it from the first strain of ' Rock of Ages' or it was stolen from him or some of his family, is a question yet to be decided." Now, the chewink is a bird of character, and, above all things, dislikes interference, and he sings "for his own 


\section{The Coming of the Birds}

pleasure, for he frequently lets himself out lustily when he knows he is all alone," as Dr. Placzeck has said of birds in general. I shall never forget a little incident I once witnessed, in which a chewink and a cardinal grosbeak figured. They reached the same bush at the same moment, and both started their songs. The loud whistle of the redbird quite smothered the notes of the chewink, which stopped suddenly before it was through and, with a squeak of impatience, made a dash at the intruder and nearly knocked him off his perch. Such haps and mishaps as these-and they are continually occurring - can only be seen in April or earlier, when we can see through the woods, and not merely the outer branches of the trees when in leaf. In April we can detect, too, the earliest flowers, and they fit well with the songs of the forerunning birds. There is more, I think, for all of us in an April violet than in a June rose; in a sheltered bit of turf with sprouting grass than in the wide pastures a month later. We do not hurry in-doors at the sudden coming of an April shower. The rain-drops that cling to the opening leaf-buds are too near real gems not to be 


\section{The Coming of the Birds $8 \mathrm{I}$}

fancied a veritable gift to us, and we toy with the baubles for the brief moment that they are ours. The sunshine that follows such a shower has greater magic in its touch than it possesses later in the year; the buds of the morning now are blossoms in the afternoon, so quickening is the warmth of the first few days of spring. The stain of winter is washed away by an April shower, and the freshest green of the pasture is ever that which is newest. There is at times a subtle element in the atmosphere that the chemist calls "ozone," but a better name is " snap." It dwells in April sunshine and is the inveterate foe of inertia. It moves us, whether we will or not, and we are now in a hurry even when there is no need of haste. The "spring fever" that we hear of as a malady in town never counts as its victim the lover of an April outing. The beauty of novelty is greater than the beauty of abundance. Our recollection of a whole summer is but dim at best, but who forgets the beginnings thereof? We passed by unheeding many a sweet song before the season was over, but can recall, I venture to say, our first glimpse of the returning spring. Though the sky may be 


\section{The Coming of the Birds}

gray, the earth brown, and the wind out of the north, let a thrush sing, a kinglet lisp, a crested tit whistle, and a tree-sparrow chirp among the swelling leaf-buds, and you have seen and heard that which is not only a delight in itself, but the more pleasing that it is the prelude announcing the general coming of the birds. 


\section{THE BUILDING OF THE NEST}

THERE are probably very few children 1 who are not more or less familiar with birds' nests, for they are not by any means confined to the country, but are to be found in the shade trees of every village street, to say nothing of the old-time lilac hedges, gooseberry bushes, and homely shrubbery of fifty years ago. Even in our large cities there are some few birds brave enough to make their homes in or very near the busiest thoroughfares. As an instance, it was not so long ago that a yellow-breasted chat-a shy bird-nested in the yard of the Pennsylvania Hospital, at the corner of Eighth and Spruce Streets, Philadelphia, and soon learned to mimic many a familiar street sound. Such instances as these were more common 


\section{The Building of the Nest}

before the unfortunate blunder of introducing the English sparrow. But it is in the country only that we find boys really posted in the matter of nests, and I wish I could add that they always adopt the rules of "hands off" when these nests come under their notice. It means far more mischief than most people think to disturb a nest, and so let every boy decide that he will not be guilty of such wanton cruelty. This, however, does not shut off every boy and girl in the land from studying these nests, and a more delightful subject can never come under youthful investigation.

What is a bird's nest? Every one knows, after a fashion, and yet few have ever considered how much that bunch of twigs, hollow in a tree, or hole in the ground really means. Like so much that is familiar, we glance at it in a careless way and never stop to consider its full significance. Except in a very few instances, a bird's nest is never the result of a single individual's labor. Even if but one bird does all the work, there has previously been a decision reached by two birds as to where the nest shall be placed, and how much this means! At once we are 


\section{The Building of the Nest 85}

brought to consider that an interchange of thought has taken place. The pair have discussed, literally, the merits and drawbacks of the situation, and have had in mind not only their own safety, but that of their offspring. The fact that they make mistakes at times proves this. Were this not the case, or if nests were placed hap-hazard in any tree or bush or anywhere on the ground, bird enemies would have a happy time for a short season, and then birds, like many of the world's huge beasts, would become extinct. On the contrary, birds have long since learned to be very careful, and their ingenuity in this apparently simple matter of choosing a nest site is really astonishing. This, too, has resulted in quickening their wits in all directions, and the bird that is really a booby is scarcely to be found.

Birds suffer at times from their misjudgment or over-confidence, and this, it must be added, reflects upon us. The instances are numberless where birds have quickly learned that certain people love them, and they lose all fear. Again, naturally very timid birds soon learn when they are free from persecution. The writer frequently passes in the 


\section{The Building of the Nest}

cars by a zoological garden on the bank of a river, and has been impressed with the abundant illustration of birds' intelligence to be noticed there. The crows have learned that fire-arms are not allowed to be used anywhere near, and so they fearlessly hop about not only the enclosure of the garden, but the many tracks of the railroad just outside, showing no timidity even when the locomotives rush by. Stranger still, wild ducks gather in the river almost directly under the railroad bridge, and do not always dive out of sight as the trains pass by, and I have never seen them take wing, even when the whistle blew the quick, short, penetrating danger signal.

To come back to their nests: birds have other enemies than man to guard against, and so are never in a hurry in the matter of determining where to build. Time and again a location has been discovered to be unsuitable after a nest has been commenced, and the structure abandoned. I have observed this many times. Indeed, my own curiosity has led the birds to move, they not quite approving my constant watching of what was going on. I well remember seating myself once in a shady 


\section{The Building of the Nest 87}

nook to eat my lunch, and being almost attacked by a pair of black-and-white treecreeping warblers. Their actions were plainly a protest against my staying where I was, and on looking about, I found that I had almost sat upon their nest, which was then just completed, but contained no eggs. I visited the spot the next day and found a single egg; but my coming was a mistake, for the birds now believed I had sinister designs, and abandoned their new-made home.

The method of building, of course, varies as much as the patterns of nests. Even when the same materials are used, they are differently treated, and a nest of sticks only may in one case be merely thrown together, as it were, while in another they are so carefully interlaced that the structure is a basket, and holds together if held by the rim only. Another, the same in general appearance, would immediately fall to pieces if similarly treated. A reason for this is discoverable in sorne cases, but not in all. If we examine a great many nests, the rule will hold good, I think, that where they are very loosely put together, the locality is such that no natural disturbing causes, as high winds, are likely to 


\section{The Building of the Nest}

bring disaster. Until I studied this point the occurrence of exceedingly frail nests was ever a matter of surprise, for it is to be remembered that the same species, as a cat-bird or cardinal red-bird, does not build after a uniform fashion, but adapts its work to the spot chosen for the nest. It would be very hazardous to say that a nest was built by this or that bird, unless the builder was seen in possession.

So difficult is it to watch a pair of birds while building, that the method of their working is largely to be guessed at from the work itself, but by means of a field-glass a good deal can be learned. It would appear as if a great many twigs were brought for the foundation of a nest, such as a cat-bird's or song-sparrow's, that were unsuitable. I have occasionally seen a twig tossed aside with a flirt of the head very suggestive of disappointment. The builders do not always carry with them a distinct idea of what they want when hunting for material, and so labor more than would be necessary if a little wiser. Very funny disputes, too, often arise, and these are most frequent when wrens are finishing their huge structures in a box or some corner 


\section{The Building of the Nest 89}

of an out-building. A feather, or a bit of thread, or a small rag will be carried in by one bird and tossed out by the other with a deal of scolding and "loud words" that is positively startling. But when the framework of any ordinary open or cup-shaped nest is finally completed, the lining is not so difficult a matter. Soft or yielding materials are used that to a greater or less extent have a " felting property," and by the bird's weight alone assume the shape desired. This is facilitated by the bird in two ways: the builder sits down, as if the eggs were already laid, and with its beak pushes the loose material between it and the framework, and tucks odd bits into any too open crevices. While doing this, it slowly moves around until it has described a complete circle. This brings to light any defeets in the outer structure, and the bird can often be seen tugging away at some projecting end, or its mate, outside of the nest, rearranging a twig here and there, while the other bird-shall I say?is giving directions.

Surprise has often been expressed that the common chipping sparrow can so neatly curl a long horse-hair into the lining of its 


\section{The Building of the Nest}

little nest. It cannot be explained, perhaps, but we have at least a clue to it. One end of the hair is snugly tucked in among stouter materials, and then,-I ask the question only, -as the bird coils it about the sides of the nest with its beak, does it break or dent it, or is there some chemical effect produced by the bird's saliva? The hairs do not appear to be merely dry-curled, for in that case they would unroll when taken from the nest, and such as $I$ have tried, when just placed in position, retained the coiled condition when removed. But old hair, curled by long exposure to the air and moisture, is often used, and this is far more tractable. When we come to examine woven nests, such as the Baltimore oriole and the red-eyed vireo, as well as some other small birds, build, there is offered a great deal more to study, for how they accomplish what they do, with their only tools their feet and beak, is not wholly known. That the tropical tailor-bird should run a thread through a leaf and so bring the edges together and make a conical-shaped bag, is not so very strange. It is little more than the piercing of the leaf and then putting the thread through the hole. 'This is ingenious 


\section{The Building of the Nest 9 I}

but not wonderful, because not difficult; but let us consider a Baltimore oriole and his nest. The latter is often suspended from a very slender elm or willow twig, and the bird has a hard time to hold on while at work. One experienced old oriole has for years built in the elm near my door, and occasionally I have caught a glimpse of him. I will not be positive, but believe that his first move is to find a good stout string, and this he ties to the twig. I use the word " tie" because I have found in many cases a capitally-tied knot, but how the bird, or birds, could accomplish this I cannot imagine. Both feet and beak, I suppose, are brought into play, but how? To get some insight into the matter, I once tied a very long string to the end of a thread that the oriole had secured at one end and left dangling. This interference caused some commotion, but the bird was not outwitted. It caught the long string by its loose end and wrapped it over and over various twigs, and soon had a curious open-work bag that served its purpose admirably. The lining of soft, fluffy stuffs was soon added. This brought up the question as to whether the bird ever ties short pieces together and so makes a more 


\section{The Building of the Nest}

secure cable that gives strength to the finished nest. In examining nests, I have seen such knots as might have been tied by the birds, but there was no way to prove it. That they do wrap a string several times about a twig and then tie it, just as a boy ties his fishing-line to a pole, is certain. With my field-glass I have followed the bird far enough to be sure of this. When at work, the bird, from necessity, is in a reversed position, - that is, tail up and head down. This has an obvious advantage, in that the builder can see what is going on beneath him, and shows, too, how near the ground the nest will come when finished; but it sometimes happens that he gets so absorbed in his work that a person can approach quite near, but I never knew him to become entangled in the loose ends that hang about him.

The oriole at times offers us a wonderful example of ingenuity. It occasionally happens that too slight a twig is selected, and when the nest is finished, or, later, when the young are nearly grown, the structure hangs down too low for safety or sways too violently when the parent birds alight on it. This is a difficulty the bird has to contend with, 


\section{The Building of the Nest 93}

and he has been known to remedy it by attaching a cord to the sustaining twigs and tying them to a higher limb of the tree, thus securing the necessary stability.

A more familiar evidence of the intelligence of birds is when the vireos are disturbed by the presence of a cow-bird's egg in their nest. To get rid of it, they often build a new floor to the nest, and so leave the offending egg to spoil. But there is displayed here an error of judgment that I am surprised to find. The birds that take this trouble certainly could throw the egg out, and, I should think, preserve their own eggs, which invariably are left to decay when a new structure is reared above the old. I believe even three-storied vireos' nests have been found.

There is one common swallow that is found well-nigh everywhere, which burrows into the sand; and when we think of it, it seems strange that so aerial a bird should build so gloomy an abode for the nesting season. This bank swallow, as it is called, seleots a suitable bluff, facing water, and, with closed beak, turns round and round with its head to the ground, thus boring a hole big enough to crawl into. It turns 


\section{The Building of the Nest}

into a gimlet for the time, and uses its beak as the point of the tool. This is odd work for a bird that almost lives in the air; and then think, too, of sitting in a dark cave, sometimes six feet long, until the eggs are hatched. On the other hand, the barn swallow makes a nest where there is plenty of light and air, and is a mason rather than a carpenter or miner. The mud he uses is not mere earth and water, but is made more adherent by a trace of secretion from the bird's mouth; at least, my experiments lead me to think so. To build such a nest would be slow work did not the two birds work together and carry their little loads of mortar with great rapidity. They waste no time, and use only good materials, for I have noticed them, when building, go to a quite distant spot for the mud when a pool was directly outside of the barn in which they were building. To all appearance the nest is of sun-dried mud, but the material has certainly undergone a kind of puddling first that makes it more adherent, bit to bit, and the whole to the rafter or side of the building. Again, these swallows have the knack of carrying a little water on the feathers of 


\section{The Building of the Nest 95}

their breasts, I think, and give the structure a shower-like wetting from time to time. At last the structure "sets" and is practically permanent.

There are birds that build no nests, like the kill-deer plover and the woodcock, and yet they exercise a faculty of equal value in. tellectually; for to be able to locate a spot that will be in the least degree exposed to danger is a power of no mean grade. The kill-deer will place its eggs on sloping ground, but somehow the heaviest dashes of rain do not wash out that particular spot. There are sand-pipers that lay their eggs on a bit of dead grass, just out of reach of the highest tides. As we look at such nests, we conclude that the birds trust a great deal to good luck; but, as a matter of fact, the destruction of eggs when in no nests, or next to none, is very small. Why, on the other hand, wood peckers should go to such an infinity of trouble to whittle a nest in the firm tissue of a living tree, when a natural hollow would serve as well, is a problem past finding out. I have even seen a woodpecker make a new nest in a tree which already contained one in every respect as good. 


\section{The Building of the Nest}

Going back to the fields and thickets, it will be seen that birds, as a rule, desire that their nests should be inconspicuous, and their efforts are always largely in this direction in the construction. The foliage of the tree or bush is considered, and when not directly concealed by this, the nest is made to look marvellously like a natural production of the vegetable world, as the beautiful nest of our wood pee-wee or the humming-bird shows. These nests are then not merely the homes of young birds, but are places of defence against a host of enemies. The parent birds have no simple task set before them that can be gone through with mechanically year after year. Every season new problems arise, if their favorite haunts suffer change, and every year the birds prove equal to their solution. 


\section{CORN-STALK FIDDLES}

$\mathrm{T} T$ is a merit of our climate that at no time 1 of the year are we, as children, shut out from healthy out-door pleasure. There are shady nooks along our creeks and rivers and delightful old mill-ponds wherein we may bathe in midsummer, and there are acres of glassy ice over which to skate in midwinter. Spring and autumn are too full of fun to particularize, the average day being available for scores of methods whereby to make life a treasure beyond compare, spending it, to the mind of a boy, in that most rational way, having sport. I do not know why we always played marbles at one time of the year and flew our kites at another: this is for the folk-lore clubs to fathom. Suffice it, that there has been for centuries a time for every out-door amusement as fixed as the phases of the moon. So much for the sport common

r $g$

9 
to all boys. And now a word concerning an old-time musical instrument that may be now quite out of date,-the corn-stalk fiddle.

This very primitive musical instrument is associated with the dreamy Indian-summer days of late November. Then it discoursed delicious music, but at other times it would have been " out of tune and harsh." Did the Indians give the secret to the children of our colonial forefathers? It would be a pleasing thought whenever the toy comes to mind, as the mere suggestion is a pleasant fancy.

The husking over, the corn-stalks carted and stored in a huge rick by the barn-yard, the apples gathered, the winter wood cut, and then the long quiet, with almost nothing to do. Such was the routine when I was a boy, and if the uncertain, dreamy days would only come, there was sure to be a short round of pleasure wherein the fiddle figured more prominently than all else.

It was no small part of the fun to see Billy make a fiddle; it was such a curious combination of mummery and skill. Having whetted his keen, old-fashioned Barlow knife on the toe of his boot, he would flourish it above his head with a whoop as though he was 


\section{Corn-stalk Fiddles}

looking for an enemy instead of a corn-stalk. Finding one that was glossy and long enough between the joints, he would press it gently between his lips, trying the several sections, and then selecting the longest and most glossy one. So much of the proceeding was for our benefit, as the cunning old fellow well knew that it added to his importance in our eyes.

What followed was skill. Having cut off the stalk above and below the ring-like joints, he had now a convenient piece about eight or ten inches in length. This he warmed by rubbing it violently with the palm of his hand, and then placing the point of the knife as near the joint as practicable, he drew it quickly down to the next joint or lower end. It must be a straight incision, and Billy seldom failed to make it so. A parallel one was then made, not more than one-sixteenth of an inch distant. A space of twice this width was left, and two or three more strings were made in the same manner. These were freed of the pith adhering to their under sides, and held up by little wooden "bridges," one at each end. The bow was similarly fashioned, but was made of a more slender section of corn-stalk and had but two strings. 
It was indeed surprising how available this crude production proved as a musical instrument. Youth and the environment counted for a great deal, of course, and my Quaker surroundings forbidding music, it was a sweeter joy because a stolen one.

I can picture days of forty years ago as distinctly as though a matter of the present. My cousin and myself, with Black Billy, would often steal away and carry with us one of the smaller barn doors. This we would place in a sunny nook on the south side of the stalk-rick, and while the fiddle was being made, would part with our jackets that we might dance the better. Billy was soon ready, and with what a joyful grin, rolling of his huge black eyes, and vigorous contortion of the whole body would our faithful friend draw from the corn-stalk every note of many a quaint old tune! And how we danced! For many a year after the old door showed the nail-marks of our heavilyheeled shoes where we had brought them down with a vigor that often roused the energy of old Billy, until he, too, would stand up and execute a marvellous pas seul. Then, tired out, we would rest in niches in the stalk-rick, 


\section{Corn-stalk Fiddles}

and Billy would play such familiar airs as had penetrated even into the quiet of Quakerdom. It was no mere imitation of the music, but the thing itself; and it would be an hour or more before the fiddle's strings had lost their tension, the silicious covering had worn away, and the sweet sounds ceased.

Almost the last of my November afternoons passed in this way had a somewhat dramatic ending. The fiddle was one of more than ordinary excellence. In the height of our fun I spied the brim of my grandfather's hat extending an inch or two around the corner. I gave no sign, but danced more vigorously than ever, and as the music and dancing became more fast and furious the crown of his stiff hat appeared, and then my grandfather's face. His countenance was a study. Whether to give the alarm and run or to remain was the decision of an instant. I gave no sign, but kept one eye on him. "Faster!" I cried to Billy, and, to my complete astonishment, the hat moved rapidly up and down. Grandfather was keeping time! “Faster!" I cried again, and the music was now a shricking medley, and the broad-brimmed hat vibrated wonderfully 


\section{IO2 Corn-stalk Fiddles}

fast. It was too much. I gave a wild yell and darted off. Circling the barn and stalkrick, I entered the front yard with a flushed but innocent face, and met grandpa. $\mathrm{He}$, too, had an innocent, far-away look, but his hat was resting on the back of his head and his cheeks were streaming with perspiration, and, best of all, he did not seem to know it. "Grandpa," I asked at the supper-table that evening, "does thee know why it is that savage races are so given to dancing?"

"Charles," he replied, gravely, and nothing more was said. 


\section{THE OLD KITCHEN DOOR}

7 HE white porch, with its high roof and 1 two severely plain pillars to support it; the heavy door, with its ponderous knocker; the straggling sweetbrier at one side; the forlorn yellow rose between the parlor windows; the grass that was too cold to welcome a dandelion; the low box hedge, and one huge box bush that never sheltered a bird's nest; all these were in front to solemnly greet that terror of my early days, -company.

To me these front-door features all meant, and still mean, restraint; but how different the world that lingered about the old farmhouse kitchen door! There was no cold formality there, but freedom,-the healthy freedom of old clothes, an old hat; ay, even the luxury of an open-throated shirt was allowed. 


\section{IO4 The Old Kitchen Door}

After a tramp over the meadows, after a day's fishing, after the round of the rabbittraps in winter, what joy to enter the kitchen door and breathe in the delectable odor of hot gingerbread! There were appetites in those days.

I do not understand the mechanism of a modern kitchen: it looks to me like a small machine-shop; but the old farm kitchen was a simple affair, and the intricacies and mystery lay wholly in the dishes evolved. It is said of my grandmother that a whiff of her sponge-cake brought the humming-birds about. I do know there was a crackly crust upon it which it is useless now to try to imitate.

But the door itself-we have none such now. It was a double door in two ways. It was made of narrow strips of oak, oblique on one side and straight on the other, and so studded with nails that the whole affair was almost half metal. It was cut in two, having an upper and a lower section. The huge wooden latch was hard and smooth as ivory. At night the door was fastened by a hickory bar, which, when I grew strong enough to lift it, was my favorite hobby-horse. 


\section{The Old Kitchen Door 105}

The heavy oak sill was worn in the mid. dle until its upper surface was beautifully curved, and to keep the rain out, when the wind was south, a canvas sand-bag was rolled against it. A stormy-day amusement was to pull this away on the sly, and sail tiny paper boats in the puddle that soon formed on the kitchen floor. There was mischief in those days.

Kitchens and food are of course inseparably conneeted, and what hunting-ground for boys equal to the closets where the cakes were kept? I do not know that the matter was ever openly discussed, but as I look back it seems as if it was an understood thing that, when our cunning succeeded in outwitting auntie, we could help ourselves to jumbles. Once I became a hero in this line of discovery, and we had a picnic behind the lilacs; but, alas! only too soon we were pleading for essence of peppermint. Overeating is possible, even in our teens.

Recent raids in modern kitchen precinets are never successful. Of late I always put my hand in the wrong crock, and find pickles where I sought preserves. I never fail, now, to take a slice of a reserved cake, or 


\section{I06 The Old Kitchen Door}

to quarter the pie intended for the next meal. Age brings no experience in such matters. It is a case where we advance backward.

Of the almost endless phases of life centring about the kitchen door there is one which stands out so prominently that it is hard to realize the older actor is now dead and that of the young on-lookers few are left. Soon after the dinner-horn was sounded the farm hands gathered at the pump, which stood just outside the door, and then in solemn procession filed into the kitchen for the noonday meal. All this was prosy enough, but the hour's nooning after it,-then there was fun indeed.

Scipio-“Zip," for short-was not illnatured, but then who loves too much teasing? An old chestnut burr in the grass where he was apt to lie had made him suspicious of $\mathrm{me}$, and I had to be extra cautious. Once I nearly overstepped the mark. Zip had his own place for a quiet nap, and, when stretched upon the grass under the big linden, preferred not to be disturbed. Now it occurred to me to be very funny. I whittled a cork to the shape of a spider, added mon- 


\section{The Old Kitchen Door 107}

strous legs, and with glue fastened a dense coating of chicken-down over all.

It was a fearful spider.

I suspended the sham inseet from a limb of the tree so that it would hang directly over Zip's face as he lay on the ground, and by a black thread that could not be seen I could draw it up or let it down at pleasure. It was well out of sight when Zip fell asleep, and then I slowly lowered the monster until it tickled his nose. It was promptly brushed aside. This was repeated several times, and then the old man awoke. The huge spider was just touching his nose, and one glance was enough. With a bound and a yell he was up and off, in his headlong flight overturning the thoughtless cause of his terror. I was the more injured of the two, but never dared in after-years to ask $\mathrm{Zip}$ if he was afraid of spiders.

And all these years the front door never changed. It may have been opened daily for aught I know, but I can remember nothing of its history.

Stay! As befitting such an occurrence, it was open once, as I remember, when there was a wedding at the house; but of that 


\section{Io8 The Old Kitchen Door}

wedding I recall only the preparations in the kitchen for the feast that followed; and, alas! it has been opened again and again for funerals.

Why, indeed, should the front door be remembered? It added no sunshine to the child's short summer; but around the corner, whether dreary winter's storm or the fiercest heat of August fell upon it, the kitchen door was the entrance to a veritable elysium. 


\section{UP $\tau H E$ CREEK}

"HERE is greater merit in the little word 1 "up" than in "down." If, when in a place new to me, I am asked to go "up the creek," my heart leaps, but there is less enthusiasm when it is suggested to go down the stream. One seems to mean going into the country, the other into the town. All this is illogical, of course, but what of that? The facts of a case like this have not the value of my idle fancies. After all, there is a peculiar merit in going up-stream. It is something to be going deeper and deeper into the heart of the country. It is akin to getting at the foundations of things.

In the case of small inland streams, generally, the mouth is a commonplace affair. The features that charm shrink from the fateful spot, and we are put in a condition of anticipation at the start which, happily, 
proves one of abundant realization at the finish.

A certain midsummer Saturday was not an ideal one for an outing, but with most excellent company I ventured up the creek. It was my friend's suggestion, so I was free from responsibility. Having promised nothing, I could in no wise be justly held accountable. Vain thought! Directly I suffered in their estimation because, at mere beck and nod, polliwogs were not forthcoming and fishes refused to swim into my hand. What strange things we fancy of our neighbors! Because I love the wild life about me, one young friend thought me a magician who could command the whole creek's fauna by mere word of mouth. It proved an empty day in one respect, animal life scarcely showing itself. To offer explanations was of no avail, and one of the little company recast her opinions. Perhaps she even entertains some doubt as to my having ever seen a bird or fish or the coveted polliwog.

It is one thing to be able to give the name and touch upon the habits of some captured creature, and quite another to command its immediate presence when we enter its haunts. 


\section{Up the Creek}

This always should, and probably never will, be remembered.

But what of the creek, the one-time BigBird Creek of the Delaware Indians? With ill-timed strokes we pulled our languid oars, and passed many a tree, jutting meadow, or abandoned wharf worthy of more than a moment's contemplation. But, lured by the treasure still beyond our reach, we went on and on, until the trickling waters of a hillside spring proved too much for us, and, turning our prow landward, we stopped to rest.

Among old trees that afforded grateful shade, a spring that bubbled from an aged chestnut's wrinkled roots, a bit of babbling brook that too soon reached the creek and was lost, and, beyond all, wide-spreading meadows, boundless from our point of view -what more need one ask? To our credit, be it said, we were satisfied, except, perhaps, that here, as all along our course, polliwogs were perverse. Birds, however, considerately came and went, and even the shy cuckoo deigned to reply when we imitated his dolorous clucking. A cardinal grosbeak, too, drew near and whistled a welcome, and once eyed us with much interest as we sat lunching 


\section{12}

\section{Up the Creek}

on the grass. What did he think of us? Eating, with him, is so different a matter, and perhaps he could give us a few useful hints. The trite remark, "Fingers came before forks," has a significance in the woods, if not in the town. While eating we listened, and I heard the voices of nine different birds. Some merely chirped in passing, it is true, but the marsh-wrens in the cat-tail thicket just across the creek were not silent for a moment. Here in the valley of the Delaware, as I recently found them on the shores of Chesapeake Bay, the wrens are quite nocturnal, and I would have been glad to have heard them sing in the moonlight again; for our enthusiasm would have been strengthened by a few such glimpses of the night side of Nature.

No bird is so welcome to a mid-day camp as the white-eyed vireo, and we were fortunate in having one with us while we tarried at the spring. Not even ninety degrees in the shade has any effect upon him, and this unflagging energy reacts upon the listener. We could at least be so far alive as to give him our attention. Mid-day heat, however, does affect many a song-bird, and now that nesting is well-nigh over, the open woods 


\section{Up the Creek}

are deserted for hidden cool retreats, where the songster takes its ease, as we, far from town, are taking ours. There is much in common between birds and men.

How, as we lingered over our glasses, counting the lemon-seeds embedded in sugar, we would have enjoyed a wood-thrush's splendid song or a rose-breasted grosbeak's matchless melody! but the to-wbee of the pipilo scratching among dead leaves, the plaint of an inquisitive cat-bird threading the briers, the whir of a humming-bird vainly seeking flowers,-these did not pass for nothing; and yet there was comparative silence that suggested a sleeping rather than a wakeful, active world.

Here let me give him who loves an outing a useful hint : be not so anxious for what may be that you overlook that which is spread before you. More than once to-day our discussion of the "silence" of a midsummer noontide drowned the voices of singing-birds near by.

How often it has been intimated to us that " two's company and three's a crowd"! but to really see and hear what transpires in the haunts of wild life, one is company and two's 


\section{4 Up the Creek}

a crowd. We cannot heed Nature and fellow-man at the same moment; and as to the comparative value of their communications, each must judge for himself.

Certainly the human voice is a sound which animals are slow to appreciate. How often have $I$ stood in silence before birds and small animals and they have shown no fear! A movement of my arms would put them on guard, perhaps; but a word spoken, and away they sped. Not a bird, I have noticed, is startled by the bellow of a bull or the neigh of a horse, and yet my own voice filled them with fear. Even snakes that knew me well and paid no attention to my movements were startled at words loudly spoken. It is a bit humiliating to think that in the estimation of many a wild animal our bark is worse than our bite.

A midsummer noontide has surely some merit, and when I failed to find fish, frog, or salamander for my young friend, it became necessary to point to some feature of the spot that made it worth a visit. To my discomfiture, I could find nothing. Trees have been talked of overmuch, and there were no wild flowers. The August bloom gave, as yet, only 


\section{Up the Creek}

a hint of what was coming. I had hit upon a most unlucky interim during which no man should go upon a picnic. In despair and empty-handed, we took to our boat and started up the creek. It was a fortunate move, for straightway the waters offered that which I had vainly sought for on shore. Here were flowers in abundance. The pickerel-weed was in bloom, the duil-yellow blossoms of the spatterdock dotted the muddy shores, bindweed here and there offered a single flower as we passed by, and never was golden-dodder more luxuriant. Still, it is always a little disappointing when Flora has the world to herself, and while we were afloat it was left to a few crows and a single heron to prove that she had not quite undisputed sway.

$\mathrm{UP}_{\mathrm{P}}$ the creek with many a turn and twist, and now on a grassy knoll we land again, where a wonderful spring pours a great volume of sparkling water into the creek. Here at last we have an object lesson that should bear fruit when we recall the day. Not a cupful of this clear cold water could we catch but contained a few grains of sand, and for so many centuries has this carrying of sand grains been in progress that now a great 


\section{I 6 p the Creek}

ridge has choked the channel where once rode ships at anchor. An obscure backcountry creek now, but less than two centuries ago the scene of busy industry. Perhaps no one is now living who saw the last sail that whitened the landscape. Pages of old ledgers, a bit of diary, and old deeds tell us something of the place; but the grassy knoll itself gives no hint of the fact that upon it once stood a warehouse. Yet a busy place it was in early colonial times, and now utterly neglected.

It is difficult to realize how very unsubstantial is much of man's work. As we sat upon the grassy slope, watching the outgoing tide as it rippled and broke in a long line of sparkling bubbles, I rebuilt, for the moment, the projecting wharf, of which but a single log remains, and had the quaint shallops of pre-Revolutionary time riding at anchor. There were heard, in fact, the cry of a heron and the wild scream of a hawk; but these, in fancy, were the hum of human voices and the tramp of busy feet.

The scattered stones that just peeped above the grass were not chance bowlders rolled from the hill near by, but the door-step and 


\section{Up the Creek}

foundation of the one-time warehouse. The days of buying, selling, and getting gain came back, in fancy, and I was more the sturdy colonist than the effeminate descendant. But has the present no merit? We had the summer breeze that came freighted with the odors gathered from the forest and the stream, and there were thrushes rejoicing in our hearing that the hill-sides were again as Nature made them. It meant much to us to tarry in the shade of venerable trees spared by the merchants that once collected here, whose names are now utterly forgotten. Stay! there are two reminders of ancient glory. A beech that overhangs the brook has its bark well scarred, and, now beyond decipherment, there are initials of many prominent naturalists of Philadelphia. A few rods up-stream is another beech that has remained unchanged. On it can be seen the initials T. A. C., 1819; those of the celebrated paleontologist, Conrad, born near here in 1803 .

The shadows lengthen; the cooler hours of eventide draw on; the languid thrushes are again abroad; music fills the air. We are homeward bound and hurrying down-stream. 
Our minds are not so receptive as when we started. How shrunken to a few rods is every mile! Trees, flowers, and birds are scarcely heeded; but the good gathered as we went up the creek we bring away, and, once again in the dusty village street, we realize that we have but to turn our back upon the town to find the world a picture. 


\section{A WINTER-NIGHT'S $O U T I N G$}

NOT long since $I$ was asked-and not 1 for the first time-if I could date the beginning of my taste for natural history pur. suits or give any incident that appeared to mark a turning-point in my career.

It did not seem possible to do this, on first consideration; but a recent living over of days gone by recalled an incident which happened before I was eleven years old, and, as it was almost my first regular outing that smacked of adventure, it is probable that it impressed me more forcibly than any earlier or, indeed, later events.

Heavy and long-continued rains had resulted in a freshet, and then three bitter cold days had converted a wide reach of meadows into a frozen lake. Happier conditions 


\section{I20 A Winter-Night's Outing}

could not have occurred in the small boy's estimation, and, with boundless anticipation, we went skating.

After smooth ice, the foremost requirement is abundant room, and this we had. There was more than a square mile for each of us. The day had been perfeet and the approaching night was such as Lowell so aptly describes, "all silence and all glisten."

As the sun was setting we started a roaring fire in a sheltered nook, and securely fastening our skates without getting at all chilled, started off. Then the fun commenced. We often wandered more than a mile away, and it was not until the fire was reduced to a bed of glowing coals that we returned to our starting-point.

Here a great surprise awaited us. The heat had drawn from the wooded hill-side near by many a meadow-mouse that, moved by the warmth or by curiosity, ventured as near as it dared. These mice were equally surprised at seeing us, and scampered off, but, it seemed to me, with some show of reluctance, as if a chance to warm themselves so thoroughly should not be missed.

We freshened the fire a little and fell back 


\section{A Winter-Night's Outing 12 I}

a few paces, but stood near enough to see if the mice would return. This they did in a few minutes, and, to our unbounded surprise and amusement, more than one sat up on its haunches like a squirrel. They seemed to be so many diminutive human beings about a camp-fire.

It was a sight to give rise to a pretty fairy tale, and possibly our Indians built up theirs on just such incidents. These mice were, to all appearances, there to enjoy the warmth. There was little running to and fro, no squeaking, not a trace of unusual excitement, and, although it was so cold, we agreed to wait as long as the mice saw fit to stay.

This resolution, however, could not hold. We were getting chilled, and so had to draw near. As we did this, there was a faint squeaking which all noticed, and we concluded that sentinels had been placed to warn the congregated mice of our approach.

The spirit of adventure was now upon us, and our skates were but the means to other ends than mere sport. What, we thought, of the gloomy nooks and corners where thickets stood well above the ice? We had shunned these heretofore, but without open 


\section{I22 A Winter-Night's Outing}

admission that we had any fear concerning them. Then, too, the gloomy gullies in the hill-side came to mind. Should we skate into such darkness and startle the wild life there?

The suggestion was made, and not one dared say he was afraid.

We thought of the fun in chasing a coon or skunk over the ice, and bravely we ventured, feeling our way where we knew the ice was thin and rough.

At a bend in the little brook, where a large cedar made the spot more dark and forbidding, we paused a moment, not knowing just how to proceed.

The next minute we had no time for thought. A loud scream held us almost spellbound, and then, with one dash, we sought the open meadows.

Once there, we breathed a little freer. We could see the fast-fading light of the fire, and at last could flee in a known direction if pursued. Should we hurry home? We debated this for some time, but were more fearful of being laughed at than of facing any real danger, and therefore concluded, with proper caution, to return. 


\section{A Winter-Night's Outing I 23}

Keeping close together, we entered the ravine again, stopped near the entrance and kindled a fire, and then, by its light, proceeded farther. It was a familiar spot, but not without strange features as we now saw it.

Again we were startled by the same wild cry, but for a moment only. A barn owl, I think it was, sailed by, glaring at us, as we imagined, and sought the open meadows.

We turned and followed, though why, it would be hard to say. The owl flew slowly and we skated furiously, trying to keep it directly overhead. Now we were brave even to foolhardiness, and sped away over the ice, indifferent to the direction taken. To this day I have credited that owl with a keen sense of humor.

On we went, over the meadows to where the swift but shallow creek flowed by, and then, when too late, we knew where we were. The ice bent beneath us, then cracked, and in an instant we were through it, our feet well in the mud and the water about our necks. Just how we got out I never knew, but we did, and the one dry match among us was a veritable treasure. 


\section{A Winter-Night's Outing}

It did not go out at the critical moment, but started ablaze the few twigs we hastily gathered, and so saved us from freezing. As we dried our clothes and warmed our benumbed bodies, I, for one, vowed never again to chase an owl on skates, but to go at it more soberly. From that eventful night the country has been attractive by reason of its wild life. It was there I became-if indeed I ever have become-a naturalist. 


\section{WILD LIFE IN WATER}

" THE antelope has less reason to fear the 1 lion than has the minnow to dread the pike. We think of timid antelopes and roaring lions, but the former has good use of its limbs, and so a fighting chance for its life; but the minnows have little advantage in the struggle for existence, and none at all when the predatory fishes are in pursuit of them."

This was written in a note-book more than thirty years ago, and I let it stand as evidence of how easy it is to be in error in matters of natural history.

When I went to school there was but one teacher of the five that knew anything about such matters, and he had the old-time views. Then a fish was a mere machine so far as intelligence was concerned. We were told of the cunning of foxes and the instinct of ants and bees, but never a word of fishes.

$$
\mathbf{I}^{*}
$$




\section{26 Wild Life in Water}

The truth is, I might very properly speak of wild "wit" in the water instead of "life," for there can be not the shadow of a doubt but that many of our fishes are really cunning. We need but watch them carefully to be readily convinced of this. How else could they escape danger?

The pretty peacock minnows throng the grassy beach at high tide, playing with their fellows in water just deep enough to cover them, and are, when here, very tame and careless. They even get stranded upon the airy side of Hoating leaves, and enjoy the excitement. They realize, it would seem, that where they are no pike can rush down upon them, no snake work its way unseen among them, no turtle crawl into their playground; but as the tide goes out and these minnows are forced nearer to the river's channel, they lose their carelessness and are suspicious of all about them.

To call this instinctive fear and result of heredity sounds well; but the naturalist is brought nearer to the wild life about him when he credits them simply with common sense. The charm of watching such "small deer" vanishes if we lean too much on the 


\section{Wild Life in Water}

learned and scientific solutions of the comparative psychologist, and possibly, too, we wander further from the truth. All I positively know is, that when danger really exists the minnows are aware of it; when it is absent they throw off the burden of this care, and life for a few hours is a matter of pure enjoyment.

Brief mention should be made of the protective character of the coloring of certain fishes. If such are fortunate enough to be protectively colored, there is little to be said; but are they conscious of this? Does a fish that is green or mottled green and gray keep closely to the weeds, knowing that it is safer there than when in open water or where the bottom is covered with white sand and pebbles? This may be a rather startling question, but there is warrant for the asking. Float half a day over the shallows of any broad pond or stream, study with care and without preconception the fishes where they live, and you will ask yourself not only this question, but many a stranger one. If fish are fools, how is it that the angler has so generally to tax his ingenuity to outwit them? How closely Nature must be copied to deceive a trout! 


\section{Wild Life in Water}

Having said so much of small fishes, what now of the larger ones that prey upon them ? A pike, for instance? Probably many more people have studied how to catch a pike than have considered it scientifically. It is tiresome, perhaps, but if a student of natural history really desires to know what a fish actually is, he must watch it for hours, being himself unseen.

At one time there were several large pike in my lotus pond. Under the huge floating leaves of this splendid plant they took refuge, and it was difficult to catch even a glimpse of them. At the same time the schools of minnows seemed to enjoy the sunlight and sported in the open water. More than once, however, I saw a pike rush out from its cover, and finally learned that it systematically lay in wait for the minnows; and I believe I am justified in adding that the minnows knew that danger lurked under the lotus leaves.

The situation was not so hap-hazard a one as might appear at first glance, and hours of patient watching convinced me that there was a decided exercising of ingenuity on the part of both the pike and the minnows; the for- 
mer ever on the lookout for a victim, the latter watchful of an ever-present danger. Day long it was a tragedy where brute force counted for little and cunning for a great deal.

Another very common fish in my pond was likewise very suggestive in connection with the subject of animal intelligence. I refer to the common " sunny," or " pumpkinseed." A shallow sand-nest had been scooped near shore and the precious eggs deposited. A school of silvery-finned minnows had discovered them, and the parent fish was severely taxed in her efforts to protect them.

So long as this school of minnows remained together, the sunfish, by fierce rushes, kept them back; but soon the former-was it accident or design?-divided their forces, and as the parent fish darted at one assaulting party, the other behind it made a successful raid upon the nest. This continued for some time, and the sunfish was getting quite weary, when, as if a sudden thought struck it, its tactics changed, and it swam round and round in a circle and sent a shower of sand out into the space beyond the nest. This effectually dazed the minnows. 


\section{I30 Wild Life in Water}

Little incidents like this are forever occurring and effectually set aside the once prevalent idea that fish are mere living machines. Look a pike in the eye and you will deteet something very different from mere instinctive timidity.

But fish are not the only creatures that live in the water; there are one snake and several species of turtles, and frogs, mollusks, and insects innumerable. These are too apt to be associated with the land, and, except the two latter forms, are usually thought of as taking to the water as a place of refuge, but really living in the open air. This is a great mistake. There is a lively world beneath the surface of the water, and the tragedy of life is played to the very end, with here and there a pretty comedy that wards off the blues when we look too long and see nothing but the destruction of one creature that another may live.

Here is an example of cunning or wit in a water-snake. A friend of mine was recently sitting on the bank of a little brook, when his attention was called to a commotion almost at his feet. Looking down, he saw a snake holding its head above the water, and 


\section{Wild Life in Water}

in its mouth struggled a small sunfish. Now, what was the snake's purpose? It knew very well that the fish would drown in the air, and not until it was dead could it be swallowed with that deliberation a snake loves. The creature was cunning enough to kill by easy means prey that would otherwise be difficult to overcome, for while crosswise in the snake's mouth it could not be swallowed, and if put down for an instant the chances of its recapture would be slight.

To suppose that a turtle, as you watch it crawling over the mud, has any sense of humor in its horny head seems absurd; yet naturalists have recorded their being seen at play, and certainly they can readily be tamed to a remarkable degree. Their intelligence, however, shows prominently only in the degree of cunning exhibited when they are in search of food. The huge snapper "lies in wait," and truly this is a most suggestive and comprehensive phrase. I believe, too, that this fierce turtle buries surplus food, and so gives further evidence of intellectual activity.

To realize what wild life in the water really is it must be observed where Nature 


\section{Wild Life in Water}

has placed it. It is perhaps not so much set forth by exceptional incidents that the student happens to witness as by that general appearance of common sense which is so unmistakably stamped upon even the most commonplace movements. Writers upon animal intelligence do not need to be constantly on the lookout for special exhibitions of cunning in order to substantiate the claims they make in favor of life's lower forms. It is plainly enough to be seen if we will but patiently watch whensoever these creatures come and wheresoever they go and the manner of their going and coming.

Do not be so intent upon watching for the marvellous that ordinary incidents are not seen. In studying wild life everywhere, and perhaps more particularly in the water, to be rightly informed we must see the average individual amid commonplace surroundings. Doing this, we are not misinformed nor led to form too high an opinion. It is as in the study of humanity. We must not familiarize ourselves with the mountebank, but with man. 


\section{$A N$ OLD-FASHIONED GARDEN}

THE world at large is a most intricate 1 machine, and parts viewed separately give no hint of their importance to what appear quite independent objects. Man may dissociate without destroying, but, when he does so, his constant attention must then take the place of the acts that Nature designed other conditions of life should perform. The isolated plant, for instance, is destroyed by insects unless we protect it by a glass covering or a poison-bath: Nature gave it to the birds to protect the plant, and in so doing find food for themselves. This law of interdependence is made very plain in the case of a modern garden or the trim lawns of a large city, and in less degree applies to towns and villages. The caterpillar 


\section{An Old-fashioned Garden}

nuisance that requires the collaring of shadetrees with cotton-wool to protect their foliage illustrates this; and what an example is a modern garden filled to overflowing with exotic plants! An all-important feature is wanting,--birds; for, except English sparrows, we have none, and these are worse than useless.

It was not always so, and the cause of the deplorable change is not hard to find. Whenever we chance, in our wanderings, to come upon some long-neglected corner of colonial times, there we will find the bloom and birds together. I have said " neglected;" not quite that, for there was bloom, and the birds are excellent gardeners.

Let me particularize. My garden is a commonplace affair, with the single innovation of a tub sunk in the ground to accommodate a lotus, - -so commonplace, indeed, that no passer-by would notice it; and yet during a single summer afternoon I have seen within its boundaries fifteen species of birds. At that hottest hour of the midsummer day, two P.M., while looking at the huge pink blossoms of the classic lotus, my attention was called to a quick movement 


\section{An Old-fashioned Garden I35}

on the ground, as if a rat ran by. It proved to be an oven-bird, that curious combination of thrush and sand-piper, and yet neither, but a true warbler. It peered into every nook and corner of the shrubbery, poised on the edge of the sunken lotus-tub, caught a wriggling worm that came to the surface of the water, then teetered along the fence and was gone. Soon it returned, and came and went until dark, as much at home as ever in the deep recesses of unfrequented woods. As the sun went down, the bird sang once with all the spring-tide ardor, and brought swiftly back to me many a long summer's day ramble in the country. It is something to be miles away from home while sitting on your own door-step.

Twice a song-sparrow came, bathed in the lotus-tub, and, when not foraging in the weedy corners, sang its old-fashioned song, now so seldom heard within town limits. The bird gave me two valuable hints as to garden management. Water is a necessity to birds as well as to any other form of life, and shelter is something more than a mere attraction. Was it not because the birds happened to be provided with them to-day 


\section{I36 An Old-fashioned Garden}

that I had, as I have had the summer long, more birds than my neighbors?

How seldom do we see the coral honeysuckle, and how generally the trumpet-creeper has given place to exotic vines of far more striking bloom, but, as will appear, of less utility! If the old-time vines that I have mentioned bore less showy flowers, they had at least the merit of attracting hummingbirds, that so grandly rounded out our complement of summer birds. These feathered fairies are not difficult to see, even though so small, and, if so inclined, we can always study them to great advantage. They become quite tame, and in the old-fashioned gardens were always a prominent feature by reason of their numbers. They are not forever on the wing, and when preening their feathers let the sunshine fall upon them, and we have emeralds and rubies that cost nothing, but are none the less valuable because of this. In changing the botanical features of our yards we have had but one thought, gorgeous flowers; but was it wise to give no heed to the loss of birds as the result? I fancy there are many who would turn with delight from formal clusters of 


\section{An Old-fashioned Garden 137}

unfamiliar shrubs, however showy, to a gooseberry hedge or a lilac thicket with song-sparrows and a cat-bird hidden in its shade. We have been unwise in this too radical change. We have abolished birdmusic in our eagerness for color, gaining a little, but losing more. We have paid too dear, not for a whistle, but for its loss. But it is not too late. Carry a little of the home forest to our yards, and birds will follow it. And let me here wander to an allied matter, that of the recently-established Arbor Day. What I have just said recalls it.

To merely transplant a tree, move it from one spot to another, where perhaps it is less likely to remain for any length of time than where it previously stood, is, it seems to me, the very acme of folly. The chances are many that the soil is less suitable, and so growth will be retarded, and the world is therefore not one whit the better off. There is far too much tree-planting of this kind on Arbor Day. In many an instance a plot of ground has been replanted year after year. I fancy we will have to reach more nearly to the stage of tree appreciation before Arbor Day will be a pre-eminent success. $12 *$ 


\section{I3 An Old-fashioned Garden}

Can we not, indeed, accommodate ourselves a little more to the trees growing where $\mathrm{Na}$ ture planted them? I know a village well, where the houses are placed to accommodate the trees that stood there when the spot was a wilderness. The main street is a little crooked, but what a noble street it is! I recall, as I write these lines, many a Friends' meeting-house, and one country school, where splendid oaks are standing near by, and to those who gather daily or weekly here, whether children or grown people, the trees are no less dear than the buildings beside them. The wanderer who revisits the scenes of his childhood looks first at the trees and then at the houses. Tree-worship, we are told, was once very prevalent, and it is not to be regretted that in a modified form it still remains with us.

As a practical matter, let me here throw out the suggestion that he will be doing most excellent work who saves a tree each year. This is a celebration that needs no special day set forth by legislative enactment. How often I have heard farmers remark, "It was a mistake to cut those trees down"! Of course it was. In nine cases out of ten the value 


\section{An Old-fashioned Garden 139}

of the trees felled proves less than was expected, and quickly follows the realization of the fact that when standing their full value was not appreciated. Think of cutting down trees that stand singly or in little groups in the middle of fields because it is a trouble to plant around them, or for the reason that they shade the crops too much! What of the crop of comfort such trees yield to both man and beast when these fields are pastures? "But there is no money in shadetrees." I cannot repress my disgust when I hear this, and I have heard it often. Is there genuine manhood in those who feel this way towards the one great ornament of our landscape?

It is not-more's the pity-within the power of every one to plant a tree, but those who cannot need not stand idly by on Arbor Day. Here is an instance where half a loaf is better than no bread. Many a one can plant a shrub. How often there is an unsightly corner, even in the smallest enclosure, where a tall tree would be a serious obstruction, whereon can be grown a thrifty bush, one that will be a constant source of pleasure because of its symmetry and bright foliage, 


\section{40 An Old-fashioned Garden}

and for a time doubly attractive because of its splendid blossoming! We know too little of the many beautiful flowering shrubs that are scattered through every woodland, which are greatly improved by a little care in cultivation, and which will bear transplanting. We overlook them often, when seen growing in the forest, because they are small, irregular, and often sparse of bloom, But remember, in the woods there is a fierce struggle for existence, and when this is overcome the full beauty of the shrub's stature becomes an accomplished fact.

Here is a short list of common shrubs, every one of which is hardy, beautiful in itself, and can be had without other cost or labor than a walk in the country, for I do not suppose any land-owner would refuse a "weed," as they generally call these humble plants. The spicewood (Lindera benzoin), which bears bright golden flowers before the leaves appear; the shad-bush (Amelancbier canadensis), with a wealth of snowy blossoms, which are increased in number and size by a little attention, as judicious trimming; and the "bush" of the wild-wood can be made to grow to a beautiful miniature tree. The 


\section{An Old-fashioned Garden I4I}

well-known pinxter flower (Azalea nudicaule) is improved by cultivation, and can be made to grow "stocky" and thick-set, instead of scragged, as we usually find it. Its bright pink blossoms make a grand showing in May. There is a little wild plum (Prunus spinosa) which only asks to be given a chance and then will rival the famous deutzias in profusion of bloom, and afterwards remains a sturdy tree-like shrub, with dark-green foliage that is always attractive. This, too, blooms before the foliage is developed, and hints of spring as surely as the robin's song. A larger but no less handsome bush is the white flowering thorn (Cratagus crus-galli), and there are wild spireas that should not be overlooked, and two white flowering shrubs that delight all who see them in bloom, the deer-berry (Vaccinium stamineum), and the "false-teeth" (Leucotboe racemosa). All these are spring flowers. And now a word about an August bloomer, the sweet pepper-bush (Cletbra alnifolia). This is easily grown and is a charming plant.

It happens, too, that a place can be found for a hardy climber, and as beautiful as the coral honeysuckles of our grandmother's days 


\section{I42 An Old-fashioned Garden}

is the climbing bittersweet (Celastrus scandens). The plant itself is attractive. Its vigorous growth soon covers the support provided for it, and in autumn and throughout the winter its golden and crimson fruit hangs in thick-set clusters upon every branch.

Considering how frequently near the house there are unsightly objects, and how depressing it is to be forever looking upon ugliness, it is strange that the abundant means for beautifying waste places are so persistently neglected. With one or more of the plants I have named, an eyesore may be changed to a source of pleasure, and it was Beecher, I think, who said, "A piece of color is as useful as a piece of bread." He never spoke more truly.

And what of the old-time arbors, with the straggling grape-vine, and perhaps a rude wren-box perched at the entrance? Is there better shade than the grape-vine offers, a sweeter odor than its bloom affords, or more charming music than the song of the restless house-wren? Certainly there have been no improvements upon these features of the oldtime garden: yet how seldom do we see them now! We must travel far, too, to 


\section{An Old-fashioned Garden $\quad$ I43}

find a martin-box. As a matter of fact, the bluebird, wren, and martin might, if we chose, be restored to the very hearts of our largest towns. People have no more terror for them than for the English sparrow, and they can all hold out against these piratical aliens, if we would consider their few and simple needs. The wrens need but nestingboxes with an entrance through which the shoulders of a sparrow cannot pass; and the bluebirds and martins require only that their houses be closed during the winter and very early spring, or until they have returned from their winter-quarters. This is easily done, and when the birds are ready to occupy the accommodations provided for them they will take possession and successfully hold the forts against all intruders. This is not a fancy merely, suggested as the basis of experimentation, but is the result of the experience of several people in widely-separated localities. I vividly recall visiting at a house in a large town, where purple martins for more than fifty years had occupied boxes placed upon the eaves of a one-story kitchen.

While stress is laid upon the importance of regaining the presence in town of these 


\section{I44 An Old-fashioned Garden}

birds, it must not be supposed that they are all that are available. There are scores of wild birds, known only to the ornithologist, that can be "cultivated" as readily as the wild shrubbery that under startling names figures in many a florist's catalogue. Give them a foothold, and they will come to stay. Orioles, thrushes, vireos, fly-catchers, are not unreasonably afraid of man, and would quickly acquire confidence if they were warranted in so doing. How long would a scarlet tanager or a cardinal grosbeak remain unmolested if it appeared in any city street? Here is the whole matter in a nutshell: the birds are not averse to coming, but the people will not let them. This is the more strange, when we remember that hundreds of dollars were spent to accommodate the pestiferous imported sparrow, that is and always must be a positive curse. Hundreds for sparrows, and not one cent for a bluebird! While the mischief can never be undone, it can be held in check, if we will but take the trouble, and this is a mere matter of town-garden rearrangement; and why, indeed, not treat our ears to music as well as our eyes to color and our palates to sweetness? Plant here 


\section{An Old-fashioned Garden I 45}

and there a bush that will yield you a crop of birds. That this may not be thought merely a whim of my own, let me quote from the weather record of Dr. John Conrad, who for forty years was the apothecary of the Pennsylvania Hospital, in Philadelphia. This institution, bear in mind, is in the heart of the city, not in its outskirts. Under date of March 23, 1862, he records, "Crocus and snow-drop came into bloom last week and are now fully out." Again, he says, "Orioles arrived on April 8, after the fruit-trees burst into bloom." Here we have a migratory bird in the city three weeks earlier than its usual appearance in the country, but I do not think the doctor was mistaken. I have positive knowledge of the fact that he was a good local ornithologist. Under date of June, I 866, Conrad writes, “A very pleasant June. Fine bright weather, and only one week too warm for comfort. The roses bloomed well (except the moss-rose) and for the most part opened better than usual. The garden full of birds, and insects less abundant than usual. Many blackbirds reared their young in our trees, and as many as sixteen or twenty have been counted on the lawn at one time. Cat-

G $k$ 


\section{I46 An Old-fashioned Garden}

birds, orioles, thrushes, wrens, vireos, robins, etc., abound and make our old hospital joyous with their sweet songs."

During the summer of 1892 I was twice in the hospital grounds, with which I was very familiar during my uncle's-Dr. Conrad's-lifetime, and I heard only English sparrows, although I saw two or three native birds. It was a sad change. Think of being able to speak of your garden as "full of birds," - as " joyous with their sweet songs." This, not long ago, could truthfully be done. Will it ever be possible to do so again? 


\section{$A N$ INDIAN TRAIL}

$\mathrm{T}$ was a strange coincidence. A farmer 1 living near by employed an Indian from the school at Carlisle, and now that the work of the summer was over, this taciturn youth walked daily over a hill to a school-house more than a mile away, and the path leading to it was an Indian trail.

Not long since I met the lad on this very path returning from school, and when he passed I stood by an old oak and watched him until lost among the trees, walking where centuries ago his people had walked when going from the mountain village and rock shelters along an inland creek to the distant town by the river.

As you looked about from the old oak there was no public road or house in sight; nothing but trees and bushes, huge rocks, and one curious jutting ledge that tradition holds is a 


\section{I48 An Indian Trail}

veritable relic of prehistoric time,- - a place where council fires were lit and midnight meetings held.

Whether tradition is true or not, the place was a fitting one whereat to tarry and fall a-thinking. Happy, indeed, could the old oak have spoken.

Many a public road of recent date has been built on the line of an old trail, as many a town and even city have replaced Indian villages; but take the long-settled, regions generally, the ancient landmarks are all gone, and a stray potsherd or flint arrow-point in the fields is all that is left to recall the days of the dusky aborigines.

Only in the rough, rocky, irreclaimable hills are we likely now to be successful, if such traces as a trail are sought for.

It was so here. Bald-top Hill is of little use to the white man except for the firewood that grows upon its sides and the scattered game that still linger in its thickets. As seen from the nearest road, not far off, there is nothing now to suggest that an Indian ever clambered about it. The undergrowth hides every trace of the surface; but after the leaves drop and a light snow has fallen, a curious 


\section{An Indian Trail}

white line can be traced from the base of the summit; this is the old trail.

It is a narrow path, but for so long a time had it been used by the Indians that, when once pointed out, it can still be followed without difficulty. It leads now from one little intervale to another: from farmer A to farmer B ; but originally it was part of their long highway leading from Philadelphia to Easton, perhaps. It matters not. Enough to know that then, as now, there were towns almost wherever there was land fit for dwellings, and paths that led from one to the other. It is clear that the Indians knew the whole country well. The routes they finally chose resulted from long experience, and were as direct as the nature of the ground made possible.

The study of trails opens up to us a broader view of ancient Indian life than we are apt to entertain.

We find the sites of villages on the banks of the rivers and larger inflowing streams; travel by canoes was universal. No locality was so favorable as the open valley, and here the greater number of Indians doubtless dwelt. But the river and its fertile shores 


\section{I50 An Indian Trail}

could not yield all that this people needed: they had to draw from the resources of the hills behind them. They soon marked the whole region with a net-work of trails leading to the various points whence they drew the necessities of life. The conditions of the present day are laid down on essentially the same lines as then.

An Indian town was not a temporary tent site, or mere cluster of wigwams, here to-day and miles away to-morrow; nor did these people depend solely upon the chase. Beside the trail over which I recently passed was a great clearing that had been an orchard. We can yet find many a barren spot that is rightly known to the people of to-day as an Indian field. So persistently were their cornfields cropped that at last the soil was absolutely exhausted, and has not yet recovered its fertility.

There was systematic bartering, too, as the red pipe-stonc or catlinite from Minnesota and obsidian from the more distant Northwest, found on the Atlantic coast, as well as ocean shells picked up in the far interior, all testify. There was also periodical journeying in autumn from inland to the sea-coast to 


\section{An Indian Trail}

gather supplies of oysters, clams, and other "sea food," which were dried by smoking and then "strung as beads and carried as great coils of rope" back to the hills to be consumed during the winter.

Many small colonies, too, passed the winters on the coast in the shelter of the great pine forests that extended to the very ocean beach. It was no hap-hazard threading of a wilderness to reach these distant points. The paths were well defined, well used. For how long we can only conjecture, but the vast accumulations of shells on the coast, often now beneath the water, point to a time so distant that the country wore a different aspect from what it now does; a time when the land rose far higher above the tide and extended seaward where now the ocean rolls resistlessly.

Returning inland, let us trace another of these old-time paths from the river-shore whereon the Indians had long dwelt, over hill and dale until we reach a valley hemmed in by low, rolling hills.

It is a pretty spot still, although marred by the white man's work; but why was it the goal of many a weary journey?

Fere is found the coveted jasper, varied in 


\section{I52 An Indian Trail}

hue as autumn leaves or a summer sunset. The quick eye of some wandering hunter, it may be, found a chance fragment, and, looking closer, saw that the ground on which he stood was filled with it; or a freshet may have washed the soil from an outcropping of the mineral. Who can tell ? It must suffice to know that the discovery was made in time, and a new industry arose. No other material so admirably met the Indian's need for arrow-points, for the blades of spears, for knives, drills, scrapers, and the whole range of tools and weapons in daily use.

So it came that mining camps were established. To this day, in these lonely hills, we can trace out the great pits the Indians dug, find the tools with which they toiled, and even the ashes of their camp-fires, where they slept by night. So deeply did the Indian work the land wheresoever he toiled that even the paths that led from the mines to the distant village have not been wholly blotted out.

The story of the jasper mines has yet to be told, and it may be long before the full details are learned concerning the various processes through which the mineral passed 


\section{An Indian Trail}

before it came into use as a finished product. Much vain speculation has been indulged in; the fancied method of reducing a thick blade to a thin one has been elaborately described, although never carried out by any human being; in short, the impossible has been boldly asserted as a fact beyond question.

The Indian's history can be read but in small part from the handiwork that he has left behind.

One phase of it, in the valley of the Delaware, is more clearly told than all else,--the advance from a primitive to a more cultured status. There were centuries during which jasper was known only as river-pebbles, and its discovery in abundance had an influence upon Indians akin to that upon Europe's stone-age people when they discovered the use of metals. At least here in the valley of the Delaware this is true.

It is vain to ask for the beginning of man's career in this region; what we find but hints at it. But he came when there were no trails over the hills, no path but the icy river's edge; only as the centuries rolled by was the country developed to the extent of knowing every nook and corner of the land, and high- 


\section{I54 An Indian Trail}

ways and by-ways became common, like the roads that now reach out in every direction.

A " trail," then, has a wealth of meaning, and those who made it were no "mere savages," as we so glibly speak of the Indians, thanks to the average school-books.

The haughty Delawares had fields and orchards; they had permanent towns; they mined such minerals as were valuable to them; they had weapons of many patterns; they were jewellers in a crude way, and finished many a stone ornament in a manner that still excites admiration. They were travellers and tradesmen as well as hunters and warriors.

Although my day's search for relics of these people had yielded but a few arrow-points, potsherds, and a stone axe, when I saw the Indian on his way from school, walking in the very path his people had made long centuries ago, the story of their ancient sojourn here came vividly to mind in the dim light of an autumn afternoon, when a golden mist wrapped the hills and veiled the valleys beyond, and I had a glimpse of pre-Columbian America. 


\section{A PRE-COLUMBIAN}

\section{DINNER}

A PONDEROUS geologist, with weighty A tread and weightier manner, brought his foot down upon the unoffending sod and declared, "These meadows are sinking at a rapid rate; something over two feet a century." We all knew it, but Sir Oracle had spoken, and we little dogs did not dare to bark.

Not long after I returned alone to these illfated meadows and began a leisurely, all-day ramble. They were very beautiful. There was a wealth of purple and of white boneset and iron-weed of royal dye. Sunflower and primrose gilded the hidden brooks, and every knoll was banked with rose-pink centaury. Nor was this all. Feathery reeds towered above the marsh, and every pond was empurpled with pontederia and starred with 


\section{56 A Pre-Columbian Dinner}

lilies. Afar off, acres of nut-brown sedge made fitting background for those meadow tracts that were still green, while close at hand, more beautiful than all, were struggling growths held down by the golden-dodder's net that overspread them.

It does not need trees or rank shrubbery to make a wilderness. This low-lying tract today, with but a summer's growth above it, is as wild and lonely as are the Western plains. Lonely, that is, as man thinks, but not forsaken. The wily mink, the pert weasel, the musk-rat, and the meadow-mouse ramble in safety through it. The great blue heron, its stately cousin, the snowy egret, and the dainty least bittern find it a congenial home.

The fiery dragon-fly darts and lazy butterflies drift across the blooming waste; bees buzz angrily as you approach; basking snakes bid you defiance. Verily, this is wild life's domain and man is out of place.

It was not always so. The land is sinking, and what now of that older time when it was far above its present level, - a high, dry, upland tract, along which flowed a clear and rapid stream ? The tell-tale arrow-point is our guide, and wherever the sod is broken 


\section{A Pre-Columbian Dinner I 57}

we have an inkling of Indian history. The soil, as we dig a little deeper, is almost black with charcoal-dust, and it is evident that centuries ago the Indians were content to dwell here, and well they might be. Even in colonial days the place had merit, and escaped not the eager eyes of Penn's grasping followers. It was meadow then, and not fitted for his house, but the white man built his barn above the ruins of his dusky predecessor's home. All trace of human habitation is now gone, but the words of the geologist kept ringing in my ears, and of late I have been digging. It is a little strange that so few traces of the white man are found as compared with relics of the Indian. From the barn that once stood here and was long ago destroyed by a flood one might expect to find at least a rusty nail.

The ground held nothing telling of a recent past, but was eloquent of the long ago. Dull indeed must be the imagination that cannot recall what has been here brought to light by the aid of such an implement as the spade. Not only were the bow and spear proved to be the common weapons of the time, but there were in even greater 


\section{58 A Pre-Columbian Dinner}

abundance, and of many patterns, knives to flay the game. It is not enough to merely glance at a trimmed flake of flint or carefully-chipped splinter of argillite, and say to yourself, "A knife." Their great variety has a significance that should not be overlooked. The same implement could not be put to every use for which a knife was needed; hence the range in size from several inches to tiny flakes that will likely remain a puzzle as to their purpose.

Besides home products, articles are found that have come from a long distance, and no class of objects is more suggestive than those that prove the widely-extended system of barter that prevailed at one time among the Indians of North America. There are shells and shell ornaments found in Wisconsin which must have been taken there from the shores of the Gulf of Mexico; catlinite or red pipe-stone ornaments and pipes found in New Jersey that could only have come from Minnesota. Shell beads are often found in graves in the Mississippi Valley that were brought from the Pacific coast, and the late Dr. Leidy has described a shell bead, concerning which he states that it is the Conus 


\section{A Pre-Columbian Dinner 159}

ternatus, a shell which belongs to the west coast of Central America. This was found, with other Indian relics, in Hartman's Cave, near Stroudsburg, Pennsylvania. Two small arrow-points found in New Jersey a year or more ago proved to be made of obsidian. These specimens could only have come from the far South-west or from Oregon, and the probabilities are in favor of the latter locality. It is not unlikely that objects like the above should find their way inland to the Great Lakes, and so across the continent and down the Atlantic coast. On the other hand, arrow-points could have had so little intrinsic value in the eyes of an Indian that we are naturally surprised that they should have been found so far from their place of origin. Obsidian has occurred but very rarely east of the Alleghanies, so far as I am aware. In the Sharples collection, at West Chester, Pennsylvania, is a single specimen, reported to have been found near that place, and a few traces have since been discovered in the uplands immediately adjoining these Delaware meadows, and really there is no reason to suppose that objects of value should not have passed quite across the continent, or been 


\section{I60 A Pre-Columbian Dinner}

carried from Mexico to Canada. There were no vast areas absolutely uninhabited and across which no Indian ever ventured.

It has been suggested that, as iron was manufactured in the valley of the Delaware as early as 1728 , the supposed obsidian arrow-points are really made of slag from the furnaces, but a close examination of the specimens proves, it is claimed, this not to have been the case, and at this comparatively late date the making of stone arrow-points had probably ceased. Just when, however, the use of the bow as a weapon was discarded has not been determined, but fire-arms were certainly common in 1728 and earlier.

A careful study, too, of copper implements, which are comparatively rare, seems to point to the conclusion that very few were made of the native copper found in New Jersey, Maryland, and elsewhere along the Atlantic coast, but that they were made in the Lake Superior region and thence gradually dispersed over the Eastern States. The large copper spear from Betterton, Maryland, recently found, and another from New Jersey, bear a striking resemblance to the spear-heads from the North-west, where unquestionably 


\section{A Pre-Columbian Dinner 161}

the most expert of aboriginal coppersmiths lived. Of course, the many small beads of this metal occasionally found in Indian graves in the Delaware Valley might have been made of copper found near by, but large masses are very seldom met with.

Speaking of copper beads recalls the fact that a necklace comprising more than one hundred was recently found on the site of an old Dutch trader's house, on an island in the Delaware. 'They were of Indian manufacture, and had been in the fur trader's possession, if we may judge from the fact that they were found with hundreds of other relics that betokened not merely European, but Dutch occupation of the spot. This trader got into trouble and doubtless deserved his summary taking off.

It is not " a most absurd untruth," as was stated not long ago in the Critic in a review of a New York history, that the Indians were " a people of taste and industry, and in morals quite the peers of their Dutch neighbors." They had just as keen a sense of right and wrong. There never was a handful of colonists in North America whose whole history their descendants would care to have known.

$$
\text { l }
$$$$
14 \text { * }
$$ 


\section{I62 A Pre-Columbian Dinner}

The truth is, we know very little of the Indian prior to European contact. Carpetknight archæologists and kid-gloved explorers crowd the pages of periodical literature, it is true, but we are little, if any, the wiser.

It is supposed, and is even asserted, that the Indian knew nothing of forks; but that he plunged his fingers into the boiling pot or held in his bare hands the steaming joints of bear or venison is quite improbable. Now, the archæologist talks glibly of bone awls whenever a sharpened splinter of bone is presented him, as if such instruments were only intended to perforate leather. They doubtless had other uses, and I am sure that more than one split and sharpened bone which has been found would have served excellently well as a one-tined fork wherewith to lift from the pot a bit of meat. Whether or not such forks were in use, there were wooden spoons, as a bit of the bowl and a mere splinter of the handle serve to show. Kalm tells us that they used the laurel for making this utensil, but I fancied my fragment was hickory. Potsherds everywhere spoke of the Indians' feasting, and it is now known that, besides bowls and shallow dishes of ordinary sizes, they also 


\section{A Pre-Columbian Dinner 163}

had vessels of several gallons' capacity. All these are broken now, but, happily, fragments of the same dish are often found together, and so we can reconstruct them.

But what did the Indians eat? Quaint old Gabriel Thomas, writing about I696, tells us that " they live chiefly on Maze or Indian Corn rosted in the Ashes, sometimes beaten boyl'd with Water, called Homine. They have cakes, not unpleasant; also Beans and Pease, which nourish much, but the Woods and Rivers afford them their provision; they eat morning and evening, their Seats and Tables on the ground."

In a great measure this same story of The Indians' food supply was told by the scattered bits found mingled with the ashes of an ancient hearth. Such fireplaces or cooking sites were simple in construction, but none the less readily recognized as to their purpose. A few flat pebbles had been brought from the bed of the river near by, and a small paved area some two feet square was placed upon or very near the surface of the ground. Upon this the fire was built, and in time a thick bed of ashes accumulated. Just how they cooked can only be conjectured, but the discovery of 


\section{I64 A Pre-Columbian Dinner}

very thick clay vessels and great quantities of fire-cracked quartzite pebbles leads to the conclusion that water was brought to the boiling-point by heating the stones to a red heat and dropping them into the vessel holding the water. Thomas, as we have seen, says corn was "boyl'd with Water." Meat also was, I think, prepared in the same manner. Their pottery probably was poorly able to stand this harsh treatment, which would explain the presence of such vast quantities of fragments of clay vessels. Traces of vegetable food are now very rarely found. A few burnt nuts, a grain or two of corn, and, in one instance, what appeared to be a charred crab-apple, complete the list of what, as yet, have been picked from the mingled earth and ashes. This is not surprising, and what we know of vegetable food in use among the Delaware Indians is almost wholly derived from those early writers who were present at their feasts. Kalm mentions the roots of the golden-club, arrow-leaf, and ground-nut, besides various berries and nuts. It is well known that extensive orchards were planted by these people. It may be added that, in all probability, the tubers of that noble plant, 


\section{A Pre-Columbian Dinner 165}

the lotus, were used as food. Not about these meadows, but elsewhere in New Jersey, this plant has been growing luxuriantly since Indian times.

Turning now to the consideration of what animal food they consumed, one can speak with absolute certainty. It is clear that the Delawares were meat-eaters. It needs but little digging on any village site to prove this, and from a single fireplace deep down in the stiff soil of this sinking meadow have been taken bones of the elk, deer, bear, beaver, raccoon, musk-rat, and gray squirrel. Of these, the remains of deer were largely in excess, and as this holds good of every village site I have examined, doubtless the Indians depended more largely upon this animal than upon all the others. Of the list, only the elk is extinct in the Delaware Valley, and it was probably rare even at the time of the European settlement of the country, except in the mountain regions. If individual tastes varied as they do among us, we have certainly sufficient variety here to have met every fancy.

With a food supply as varied as this, an ordinary meal or an extraordinary feast can readily be recalled, so far as its essential feat- 


\section{I66 A Pre-Columbian Dinner}

ures are concerned. It is now September, and, save where the ground has been ruthlessly uptorn, everywhere is a wealth of early autumn bloom. A soothing quiet rests upon the scene, bidding us to retrospective thought. Not a bit of stone, of pottery, or of burned and blackened fragment of bone but stands out in the mellow sunshine as the feature of a long-forgotten feast. As I dreamily gaze upon the gatherings of half a day, I seem to see the ancient folk that once dwelt in this neglected spot; seem to be a guest at a preColumbian dinner in New Jersey. 


\section{A DAY'S DIGGING}

As long ago as November, 1679, two A Dutchmen, Jasper Dankers and Peter Sluyter, worked their way laboriously across New Jersey from Manhattan Island, and reached South River, as the Delaware was then called, at least by the Hollanders. They were all agog to see the falls at the head of tide-water, and spent a miserable night in a rickety shanty, which was cold as Greenland, except in the fireplace, and there they roasted. All this was not calculated to put them in excellent humor, and so the next day, when they stood on the river-bank and saw only a trivial rapid where they had expected a second $\mathrm{Ni}$ agara, their disgust knew no bounds. These travel-tired Dutchmen quickly departed, rowing a small boat down-stream, and growling whenever the tide turned and they had to row against it. 
When they reached Burlington, they recorded of an island nearly in front of the village, that it "formerly belonged to the Dutch Governor, who had made it a pleasure ground or garden, built good houses upon it, and sowed and planted it. He also dyked and cultivated a large piece of meadow or marsh." The English held it at the time of their visit, and it was occupied by "some Quakers," as the authors quoted called them.

One of these Dutch houses, built in part of yellow bricks, and with a red tiled roof, I found traces of years ago, and ever since have been poking about the spot, for the very excellent reasons that it is a pretty one, a secluded one, and as full of natural history attractions now as it was of human interest when a Dutch beer-garden.

Had no one who saw the place in its palmy days left a record concerning the beer, I could, at this late day, have given testimony that if there was no beer, there were beer mugs, and schnapps bottles, and wineglasses, for I have been digging again and found them all; and then the pipes and pipe-stems! I have a pile of over five hundred. The Dutch travellers were correct as to the place 


\section{A Day's Digging}

having been a pleasure-garden. It certainly was, and probably the very first on the Delaware River. But there was " pleasure," too, on the main shore, for the men who referred to the island stayed one night in Burlington, and, the next day being Sunday, attended Quaker meeting, and wrote afterwards, "What they uttered was mostly in one tone and the same thing, and so it continued until we were tired out and went away." Doubtless they were prejudiced, and so nothing suited them, not even what they found to drink, for they said, "We tasted here, for the first time, peach brandy or spirits, which was very good, but would have been better if more carefully made." They did not like the English, evidently, for the next day they went to Takanij (Tacony), a village of Swedes and Finns, and there drank their fill of "very good beer" brewed by these people, and expressed themselves as much pleased to find that, because they had come to a new country, they had not left behind them their old customs.

The house that once stood where now is but a reach of abandoned and wasting meadow was erected in 1668 or possibly 


\section{A Day's Digging}

a little earlier. Its nearest neighbor was across a narrow creek, and a portion of the old building is said to be still standing. Armed with the few facts that are on record, it is easy to picture the place as it was in the days of the Dutch, and it was vastly prettier then than it is now. The public of to-day are not interested in a useless marsh, particularly when there is better ground about it in abundance, and whoever wanders to such uncanny places is quite sure to be left severely alone. This was my experience, and, being undisturbed, I enjoyed the more my resurrective work. I could enthuse, without being laughed at, over what to others was but meaningless rubbish, and $I$ found very much that, to me, possessed greater interest than usual, because of a mingling of late Indian and early European objects. With a handful of glass, porcelain, and amber beads were more than one hundred of copper; the former from Venice, the latter the handiwork of a Delaware Indian. With a white clay pipe, made in Holland in the seventeenth century, was found a rude brown clay one, made here in the river valley. Mingled with fragments of blue and white Delft plates, bowls, and platters, were sun- 


\section{A Day's Digging}

dried mud dishes made by women hereabouts during, who can say how many centuries? How completely history and pre-history here overlapped! We know pretty much everything about Dutchmen, but how much do we really know of the native American? After nearly thirty years' digging, he has been traced from the days of the great glaciers to the beginnings of American history; but we cannot say how long a time that comprises. The winter of 1892-1893 was, so far as appearances went, a return to glacial times. Ice was piled up fifty feet in height, and the water turned from the old channel of the river. The cutting of another one opened up new territory for the relic hunter when the ice was gone and the stream had returned to its old bed. Many an Indian wigwam site that had been covered deep with soil was again warmed by the springtide sun, and those were rare days when, from the ashes of forgotten camps, I raked the broken weapons and rude dishes that the red men had discarded. It was reading history at first hands, without other commentary than your own. The ice-scored gravel-beds told even an older story; but no one day's digging was so full 


\section{A Day's Digging}

of meaning, or brought me so closely in touch with the past, as when I uncovered what remained of the old Dutch trader's house; traced the boundaries of the one-time pleasure-garden, hearing in the songs of birds the clinking of glasses, and then, in fancy, adding to the now deserted landscape the fur-laden canoes of the Indians who once gathered here to exchange for the coveted gaudy beads the skins of the many animals which at that time roamed the forests. 


\section{DRIFTING}

1 AKE an early start if you wish an only when the day is middle-aged or old? A wise German has said, "The morning hour has gold in its mouth." For many a rod after leaving the wharf the river still "smoked," and the scanty glimpses between the rolling clouds of mist spurred the imagination. There was nothing certain beyond the gunwales. The pale-yellow color of the water near at hand and the deep-green and even black of that in the distance had no daytime suggestiveness. It was not yet the familiar river with its noonday glitter of blue and silver.

It is not strange that the initial adventure to which the above-mentioned conditions naturally gave rise occurred while this state of uncertainty continued. Very soon I ran upon a $15^{*}$

I 73 


\section{74 \\ Drifting}

snag. To strike such an object in mid-river was rather startling. Was I not in or near the channel? Steamboats come puffing and plowing here and sailing craft pass up and down, so my only care had been to avoid them; but now there came in my path the twisted trunk of an old forest tree and held me fast. All the while the mist rose and fell, giving no inkling of my whereabouts. In the dim, misty light what a strange sea-monster this resurrected tree-trunk seemed to be! Its thick green coat of silky threads lay closely as the shining fur of the otter, a mane of eel-grass floated on the water, the gnarly growths where branches once had been glistened as huge eyes, and broken limbs were horns that threatened quick destruction. There was motion, too. Slowly it rose above the water and then as slowly sunk from view. Could it be possible that some long-necked saurian of the Jersey marls had come to life? Nonsense; and yet so real did it seem that I was ready for the river-horse to rise

" from the waves beneath, And grin through the grate of his spiky teeth."

With such an uncanny keeper, I was held a 
prisoner. At last I struck it with an oar to beat it back, and rocked the frail boat until $I$ feared plunging into the deep water and deeper mud beneath. Deep water? It suddenly occurred to me to try its depth, and the truth was plain. I was far from the channel, and might with safety have waded to the shore. As usual, I had rashly jumped at conclusions. The mouth of an inflowing creek was near at hand, and this sunken tree, a relic of some forgotten freshet, had been lying here in the mud for several years. The tide lifted and let fall the trunk, but the root-mass was still strongly embedded. I knew the spot of old, and now, fearing nothing, was rational again.

Such sunken trees, however, are well calculated to alarm the unthinking. It is said of one yet lying in the mud of Crosswicks Creek, that it rose so quickly once as to overturn a boat. This is not improbable. That occurrence, if true, happened a century ago, and the same tree has since badly frightened more than one old farmer. I am told this of one of them who had anchored his boat here one frosty October morning and commenced fishing. While half aslecp, or 


\section{I76 Drifting}

but half sober, the tree slowly raised up and tilted the boat so that its occupant felt compelled to swim. His view of the offending monster was much like my own fevered vision of to-day. He not only swam ashore, but ran a mile over a soft marsh. To him the seaserpent was a reality, although he saw it in the creek.

It is of interest to note that among the early settlers of this region, for at least three generations, the impression was prevalent that there might be some monster lurking in the deep holes of the creek or in the river. The last of the old hunters and fishermen of this region, who had spent all his life in a boat or prowling along shore, was ever talking of a "king tortle" that for forty years had defied all his efforts to capture it. "Mostly, it only shows its top shell, but I have seen it fair and square, head and legs, and I don't know as I care to get very close, neither." This was his unvaried remark whenever I broached the subject. To have suggested that it was a sunken $\log$, or in some other way tried to explain the matter, would only have brought about his ill will. I once attempted it, very cautiously, but he effectually 


\section{Drifting}

shut me up by remarking, "When this here creek runs dry and you can walk over its bottom, you'll larn a thing or two that ain't down in your books yet, and ain't goin' to be." The old man was right. I do not believe in " king tortles," but there certainly is "a thing or two" not yet in the books. Stay! How big do our snappers grow? Is the father of them all still hiding in the channel of Crosswicks Creek ?

A description in an old manuscript journal, of the general aspect of the country as seen from the river, bears upon this subject of strange wild beasts and monsters of the deep, as well as on that of sunken trees that endangered passing shallops.

"As we pass up the river," this observant writer records, "we are so shut in by the great trees that grow even to the edge of the water, that what may lye in the interior is not to be known. That there be fertile land, the Indians tell us, but their narrow paths are toilsome to travel and there are none [of these people] now that seem willing to guide us. As we approached ffarnsworth's the channel was often very close to the shore, and at one time we were held by 
the great trees that overhung the bank and by one that had been fallen a long time and was now lodged in the water. As I looked towards the shore, I exclaimed, "Here we are indeed in a great wilderness. What strangeness is concealed in this boundless wood? what wonder may at any time issue from it, or fierce monster not be lurking in the waters beneath us?' Through the day the cries of both birds and beasts were heard, but not always. It was often so strangely quiet that we were more affected thereby than by the sounds that at times issued forth. At night there was great howling, as we were told, of wolves, and the hooting of owls, and often there plunged into the stream wild stags that swam near to our boat. But greater than all else, to our discomfort, were the great sunken trunks of trees that were across the channel, where the water was of no great depth."

What a change! and would that this old traveller could revisit the Delaware to-day. $\mathrm{My}$ boat is free again and the mists are gone. Through the trees are sifted the level sunbeams. There is at least a chance now to compare notes. The forest is now a field, 


\section{Drifting}

the trackless marsh a meadow; wild life is largely a thing of the past; silence, both day and night, replaces sound. No, not that; but only the minor sounds are left. There are still the cry of the fish-hawk and the sweet song of the thrush. No stags now swim the river, but there remain the mink and the musk-rat. It has not been long since I saw a migration of meadow-mice, and at night, I am sure, many an animal dares to breast the stream, a mile wide though it be. Too cunning to expose itself by day, it risks its life at night; and how tragic the result when, nearly at the journey's end, it is seized by a lurking foe; dragged down, it may be, by a snake or a turtle!

The world is just as full of tragedy as ever, and, let us hope, as full of comedy. In a bit of yonder marsh, above which bends the tall wild rice, there is daily enacted scene after scene as full of import as those which caused the very forest to tremble when the wolf and panther quarrelled over the elk or decr that had fallen.

It has been insisted upon that a goal-less journey is necessarily a waste of time. If on foot, we must keep forever on the go; if 


\section{0}

Drifting

in a boat, we must keep bending to the oars. It is this miserable fallacy that makes so many an out-door man and woman lose more than half of that for which they went into the fields. Who cares if you did see a chippy at every turn and flushed a bittern at the edge of the marsh? If you had been there before them, and these birds did the walking, you would have gone home the wiser. It is not the mere fact that there are birds that concerns us, but what are they doing? why are they doing it? This the town-pent people are ever anxious to know, and the facts cannot be gathered if you are forever on the move. Suppose I rush across the river and back, what have I seen ? The bottom of the boat. I came to see the river and the sky above, and if this is of no interest to the reader, let him turn the leaf.

Does every storm follow the track of the sun? As the sun rose there were clouds in the east and south and a haziness over the western sky. Had I asked a farmer as to the weather probabilities, he would have looked everywhere but due north. Why does he always ignore that quarter? There may be great banks of cloud there, but they 


\section{Drifting}

go for nothing. " "Sou-east" and "sou-west" are forever rung in your ears, but never a word of the north. Sometimes I have thought it may be for this reason that about half the time the farmer is all wrong, and the heaviest rains come when he is most sure that the day will be clear.

Looking upward, for the sky was clear in that direction now, I saw that there were birds so far above me that they appeared as mere specks. Very black when first seen, but occasionally they flashed as stars seen by day from the bottom of a well. They could not be followed, except one that swept swiftly earthward, and the spreading tail and curve of wings told me it was a fish-hawk. What a glorious outlook from its ever-changing point of view! From its height, it could have seen the mountains and the ocean, and the long reach of river valley as well. If the mists obscure it all, why should a bird linger in the upper air? The prosy matter of foodgetting has nothing to do with it. While in camp on Chesapeake Bay, I noticed that the fish-hawks were not always fishing, and often the air rang with their strange cries while soaring so far overhead as to be plainly seen 
only with a field-glass. Every movement suggested freedom from care as they romped in the fields of space. It is not strange that they scream, or laugh, shall we say? when speeding along at such rate and in no danger of collision. If I mistake not, the cry of exultation is coincident with the downward swoop, and I thought of old-time yelling when dashing down a snow-clad hill-side; but how sober was the work of dragging the sled up-hill! The hawks, I thought, were silent when upward bound. If so, there is something akin to humanity in the hawk nature.

I have called the cry of the fish-hawk a "laugh," but, from a human stand-point, do birds laugh ? It is extremely doubtful, though I recall a pet sparrow-hawk that was given to playing tricks, as I called them, and the whole family believed that this bird actually laughed. Muggins, as we named him, had a fancy for pouncing upon the top of my head and, leaning forward, snapping his beak in my face. Once an old uncle came into the room and was treated in this fashion. Never having seen the bird before, he was greatly astonished, and indignant beyond measure when 


\section{Drifting}

the hawk, being rudely brushed off, carried away his wig. Now the bird was no less astonished than the man, and when he saw the wig dangling from his claws he gave a loud cackle, unlike anything we had ever heard before, and which was, I imagine, more an expression of amusement than of surprise. I think this, because afterwards I often played the game of wig with him, to the bird's delight, and he always "laughed" as he carried off the prize. On the contrary, the unsuccessful attempt to remove natural hair elicited no such expression, but sometimes a squeal of disgust.

In the Spectator of October I, I 892, page 444, I find a most thoughtful article, entitled "The Animal Sense of Humor," and I quote as follows: "The power of laughter is peculiar to man, and the sense of humor may be said, generally speaking, to be also his special property." Again, "We never saw the slightest approach to amusement in one animal at the mistakes of another, though dogs, so far as we can venture to interpret their thoughts, do really feel amusement at the mistakes of men." Possibly the author is right, but do not cats show a sense of humor at the rough- 


\section{84}

Drifting

and-tumble gambols of their kittens? Is not the sly cuff on the ear that sends a kitten sprawling indicative of a sense of fun on the part of tabby? Our author says, "so far as we can venture to interpret their thoughts." "Ay, there's the rub." No one can tell how far it is safe to venture, but I go a great deal beyond my neighbors. Our author concludes, "In animals, as in man, humor is the result of civilization, and not as we understand it, a natural and spontaneous development." I cannot subscribe to this. I know little of domestic animals, but have got the idea of an animal's sense of humor from wild life, and confirmed it by what I have seen of cats and dogs.

While I have been drifting, and using my eyes and ears instead of legs and arms, as is advocated, the clouds, too, have been creeping this way, and, while the morning is yet fresh, it is certainly going to rain. Had I consulted the barometer, I would have known this; but then, knowing it, might I not have stayed at home? Why not enjoy part of a day? That the rain will soon be here does not diminish one's pleasure, unless there is a fear of getting wet, and this is all too com- 


\section{Drifting}

mon. I hope that it does not mean that you have but one suit of clothes.

The approaching rain, the increasing cloudiness, the shut-in appearance, made the river exceedingly attractive. With the downdropping clouds dropped down the birds, and the swallows now skimmed the water as they had been skimming the sky. The fishhawks departed, but a host of land-birds crossed the stream, as if comparing the shelter afforded by the cedars on one side and pines on the other. These birds chattered as they flew by, and turned their heads up- and downstream, as if curious as to all that might be going on. Suddenly the water ceased to be rippled, and far down-stream a cloud appeared to have reached the river. It was the rain. It seemed to march very slowly, and every drop made a dimple on the river's breast. Then I could hear the on-coming host, the sound having a distinct bell-like tinkle as each drop touched the surface and disappeared. A curious effect, too, was produced by the wind or the varying density of the cloud above, in that the drops were very near together where I happened to be, and much farther apart and larger some distance beyond $16^{*}$ 


\section{Drifting}

the boat. I could of course make no measurements, but appearances suggested that in the middle of the river the drops were less numerous in the proportion of one to five. Does it usually rain harder over land than over water? Heretofore I had seen the rain upon the river while on shore, and was now very glad to have been caught adrift, so as to observe it from a new point of view. It was a beautiful sight, well worth the thorough wetting that I got and which drove me home soon after with pleasant thoughts of my goalless journey. 


\section{FOOTPRINT'S}

WHILE the camp-fire was smoking, for the wood was green and I was willing that my companion should worry over it, I strolled up the long, sandy beach with no particular object in mind and quite ready to meet and parley with any creature that I overtook. I saw only evidences of what had been there, or what I supposed had been. There were tracks that I took to be those of herons, and others that suggested a raccoon in search of crayfish. Here and there a mouse had hurried by. What lively times had been kept up at low tide within sight of the tent door! and yet we knew nothing of it. But these tracks were not well defined, and therefore why not misinterpreted? I have not suggested all the possibilities of the case- Here my meditations were checked by the call to breakfast, but I took up the subject again as I 
walked alone in the woods, for I was but the companion of a worker, not one myself.

It occurred to me that when we read of hunters, or perhaps have followed a trapper in his rounds, we have been led to think that footprints are animal autography that the initiated can read without hesitation. To distinguish the track of a rabbit from that of a raccoon is readily done, and we can go much further, and determine whether the animal was walking or running, made a leap here or squatted there; but can we go to any length, and decipher every impress an animal may have made in passing over the sand or mud? I think not. I have seen a twig sent spinning a long distance up the beach at low tide, making a line of equidistant marks that were extremely life-like in appearance. A cloud of dead leaves have so dotted an expanse of mud that a gunner insisted there had been a flock of plover there a few moments before he arrived. All depends, or very much does, on the condition of the surface marked. If very soft and yielding, the plainest bird-tracks may be distorted, and a mere dot, on the other hand, may have its outline so broken as to appear as though made 


\section{Footprints}

by a bird or mammal. Still, tracks are a safe guide in the long run, and, whether our opinion as to them be correct or not, the rambler finds something worth seeing, and he goes on anything but a wild-goose chase who sometimes finds himself mistaken. It is well to check our confidence occasionally and realize the limits of our power.

Opportunity afforded while in camp, and I made a short study of footprints. With a field-glass I noted many birds, and then going to the spot, examined the impressions their feet had made. A night-heron did not come down flatly upon its feet with outspread toes, and so the tracks were quite different from the impressions made when the bird walked. Crows, I noticed, both hopped and walked, and the marks were very different, the former being broad and ill-defined in comparison with the traces of the same bird's stately tread. Had the bird not been seen, any one would have supposed two creatures had been keeping close company, or that some one individual had passed by in the very path of another. The purple grakle and red-winged blackbird made tracks too much alike to be distinguished, yet these 


\section{I90 Footprints}

birds have not the same size or shape of foot. A water-snake came up over the mud and left a line of marks upon the sand that could not be recognized as that of any animal, except it might be a faint resemblance to the trail of a mussel. I chased a dozen crayfish over a mud flat, and their backward and sidewise leapings caused an old gunner to say there had been plover about. A blue-winged teal made a long double line of dents in the sand before it rose clear of the beach, and these were very like many a footprint I had previously seen. What, then, must we think of the fossil footprints of which so much has been written? As different species, a long series of these impressions in the rock have been described and given high-sounding titles. I am not entitled to an opinion, but have doubts, nevertheless, of the wisdom of considering every slightly different form as made by a different creature. I have given my reasons, and will only add another instance, one of greater significance than all as bearing upon the question. I startled a slumbering jumping-mouse last summer and it bounded across the smooth sand bared by the outgoing tide. Its track then was one made 
by its body rather than the extremities, and a curious dent in the river-shore's smooth surface it was; but before taking again to the woods it walked in its peculiar way, and the little footprints were quite distinct and unmistakably those of a small mammal. Had the two sets of markings been preserved in a slab of sandstone, no ichnologist would have recognized the truth, but probably would have said, "Here is a case where some leaping creature has overtaken a small rodent and devoured it."

Difficult as fossil footprints may be to decipher, they call up with wonderful distinctness the long ago of other geologic ages. It is hard to realize that the stone of which our houses are built once formed the tide-washed shore of a primeval river or the bed of a lake or ocean gone long before man came upon the scene.

But the footprints of to-day concern me more. Looking over the side of the boat, I saw several mussels moving slowly along and making a deep, crooked groove in the ripplemarked sand, "streaking the ground with sinuous trace," as Milton puts it; and the school of blunt-headed minnows made little 


\section{92 \\ Footprints}

dents in the sand wherever the water was shallow, when they turned suddenly and darted off-shore. This sand seemed very unstable, and a little agitation of the water caused many a mark to be wiped out; and yet we find great slabs of ripple-marked and footmarked sandstone. I picked up such a piece not long ago on which were rain-drop marks. This is the story of a million years ago; but who ever found Indian moccasin-marks not two centuries old? The footprints that could tell us many a wonderful story are all gone and the tale of a rain-drop remains. This is a bit aggravating. Here where we have pitched our camp, or very near it, was a Swedish village in 1650 and later, and for two days $I$ have been hunting for evidence of the fact,-some bit of broken crockery, rusty nail, glass, pewter spoon, anything,but in vain. History records the village, and correctly, without a doubt, but there are no footprints here, nor other trace to show that a white man ever saw the place until our tent was pitched upon the beach.

Towards evening I had occasion to renew my youth,-in other words, "run on an errand," as my mother put it,-and going half 


\section{Footprints}

a mile through the woods, I came to a narrow but well-worn path. This was so akin to my footprint thoughts of the morning that I gladly followed it instead of making a short cut. It was fortunate, for the path led directly to where I wished to go, and our theoretical geography, as usual, was terribly out of joint. As it was, on the edge of an old village I found a very old man in a very old house. His memory as to the earlier half of the century was excellent, and he gave me the desired information and more. I spoke of the path through the woods, and he chuckled to himself.

"Through the woodses, eh? Well, when I made the path, goin' and comin' through the brush that wasn't shoulder-high, there was no trees then. That was more'n forty years ago."

“ No, John, 'twa'n't," piped a weak voice from the interior of the little cottage; "s 'twa'n't mor'n "

"Laws, man, don't mind her. She disputes the almanac, and every winter gets in New Year's ahead of Christmas."

I did not stop to argue the matter, but hurried campward, glad that, if I could find

I $n$ 
no footprints of human interest and historic, I at least had followed a path made forty years ago,-a path that had been worn among bushes and now led through a forest. It was indeed suggestive. By the camp-fire that night I vowed to plant a forest where now there was but a thicket, and in my dreams I walked through a noble wood.

Think how much might be done to beautify the world, and how little is accomplished. 


\section{BEES AND BUCKWHEAT}

7 HE great storm of yesterday cleared the I air as well as cleaned the beaches, and the river was fresh and sparkling as though the tempest had added new life, so that the listless midsummery water was now as champagne, "with beaded bubbles winking at the brim." The air was heavy with sweetness and with song, the fields and meadows painted as the rose. The buckwheat was in bloom, and a million bees were humming. The pasture was gay with pink gerardia, or reflected the summer sky where the day-flower blossomed. There was no commingling of these late flowers. Each had its own acre, exercised squatter sovereignty, and allowed no trespassing. The only evidence of man's interference, except the buckwheat-field, was a dilapidated worm-fence, and this is one of several instances where beauty increases hand 


\section{I96 Bees and Buckwheat}

in hand with decay. The older such a fence, the better; when merely a support for Virginia creeper or the rank trumpet-vine, it is worthy the rambler's regard. Wild life long ago learned what a safe snug-harbor such ruined fences offer. It puzzles even a mink to thread their mazes, and the shy rabbit that has its "form" in a brier-hidden hollow of the crooked line feels that it is safe.

There are traces of these old fences of which no record remains, placed perhaps by the very earliest settler in a traet that he had cleared and which has since gone back to an almost primitive state. In an old woodland $\mathrm{I}$ once traced a fence by the long line of cypripediums in bloom, which were thriving in the mould of decayed fence-rails, a pretty if not permanent monument to departed worth.

A word more of these old fences in winter. When the snow beats across the field, it stops here and gracefully curves above it, arching the rails and vines until all is hidden, unless it be some lonely projecting stake, by which alone it communicates with the outside world. I rashly attempted once to go across-lots over a new country, and made a discovery. The snow-bound fence was but a drift, I thought, 


\section{Bees and Buckwheat}

but it proved to be far different. The thick mat of hardy growths had kept back the snow, which was but a roof and did not wholly exclude the light. For some distance I could dimly make out the various growths, and each little cedar stood up as a sentinel. A loud word sounded and resounded as if I had spoken in an empty room or shouted in a long tunnel. The coldest day in the year could not inconvenience any creature that took shelter here, and I found later that life, both furred and feathered, knew the old fence far better than I did.

But this is the last day but one of August, and so nominally the end of summer. Only nominally, for these flowery meadows and sweet-scented fields contradict the almanac. This quiet nook in the Delaware meadows offers no intimation of autumn until October, and late in the month at that. The bees and buckwheat will see to this, or seem to, which is just as much to the purpose. To-day along the old worm-fence are many kingbirds, and, although mute, they are not moping. There is too much insect life astir for that. With them are orioles and bluebirds, the whole making a loose flock of perhaps a hundred 


\section{I98 Bees and Buckwheat}

birds. The bluebirds are singing, but in a half-hearted, melancholy way, reminding me of an old man who spent his time when over ninety in humming "Auld Lang Syne." Before the buckwheat has lost its freshness these birds will all be gone, but at what time the bluebirds part company with the others I do not know. They certainly do not regularly migrate, as do the others. There was a colony of them that lived for years in and about my barn, and one was as sure to see them in January as in June. No English sparrows could have been more permanently fixed.

When the buckwheat is ripe and the fields and meadows are brown, there will be other birds to take their place. Tree-sparrows from Canada and white-throats from New England will make these same fields merry with music, and the tangle about the old fence will ring with gladness. But it is August still, and why anticipate? High overhead there are black specks in the air, and we can mark their course, as they pass, by the bell-like cbink-cbink that comes floating earthward. It is one of the sounds that recall the past rather than refer to the present. The reed-bird of to-day was a bobolink last May. His roundelay that told 


\section{Bees and Buckwheat 199}

then of a long summer to come is now but a single note of regret that the promised summer is a thing of the past. It is the Alpha and Omega of the year's song-tide. Not that we have no other songs when the reed-bird has flown to the Carolina rice-fields. While I write, a song-sparrow is reciting reminiscences of last May, and there will be ringing rounds of bird-rejoicing from November to April. Still, the initial thought holds good: bobolink in May, and only a reed-bird in August; the beginning and the end; the herald of Summer's birth and her chief mourner; Alpha and Omega.

Where the brook that drains the meadow finds its way, the little rail-birds have congregated. Many spent their summer along the Musketaquid, where Thoreau spent his best days, but they bring no message from New England. They very seldom speak above a whisper. Not so the king-rail. He chatters as he threads the marsh and dodges the great blue harrier that sweeps above the cat-tail grasses and has to be content with a sparrow or a mouse.

These late August days are too often overfull, and one sees and hears too much,-so 


\section{Bees and Buckwheat}

very much that it is hard to give proper heed to any one of the many sights and sounds. But how much harder to turn your back upon it! All too soon the sun sinks into the golden clouds of the western sky.

That was a happy day when the buckwheat was threshed in the field, on a cool, clear, crisp October morning. The thumping of the flails on the temporary floor put the world in good humor. No bird within hearing but sang to its time-keeping. Even the crows cawed more methodically, and squirrels barked at the same instant that the flail sent a shower of brown kernels dancing in the air. The quails came near, as if impatient for the grains eyes less sharp than theirs would fail to find. It was something at such a time to lie in the gathering heap of straw and join in the work so far as to look on. That is a boy's privilege which we seldom are anxious to outgrow. A nooning at such a time meant a fire to warm the dinner, and the scanty time allowed was none too short for the threshers to indulge in weather prognostications. This is as much a habit as eating, and to forego it would be as unnatural as to forego the taking of food. As the threshers ate, they scanned 
the surroundings, and not a tree, bush, or wilted weed but was held to bear evidence that the coming winter would be "open" or " hard," as the oldest man present saw fit to predict. No one disputed him, and no one remembered a week later what he had said, so the old man's reputation was safe.

The buckwheat threshed, the rest is all a matter of plain prose. Stay! In the coming Indian summer there was always a bee-hunt. The old man whom we saw in the buckwheatfield in Oetober was our dependence for wild honey, which we fancied was better than that from the hives. $\mathrm{He}$ always went alone, carrying a wooden pail and a long, slender oaken staff. How he found the bee-trees so readily was a question much discussed. " $\mathrm{He}$ smells it," some one suggested; " He hears 'em a-buzzin'," others remarked. Knowing when he was going, I once followed on the sly and solved the mystery. He went without hesitation or turning of the head to a hollow beech, and straightway commenced operations. I did not stay to witness this, but came away recalling many a Sunday afternoon's stroll with him in these same woods. What he had seen in August he had remem- 


\section{$2 \mathrm{O} 2$}

\section{Bees and Buckwheat}

bered in December, and, wise man that he was, said nothing meanwhile. Why, indeed, should he throw aside the opportunity to pose as one having superior knowledge, when others were so persistent in asserting it of him? There is that much vanity in all men.

But a year later his superior knowledge failed him. I had found the same tree in my solitary rambles, and was there ahead of him. Still, I never enjoyed my triumph. I felt very far from complimented when he remarked, as an excuse for his failure, that " a skunk had been at the only bee-tree in the woods. He saw signs of the varmint all about;" and when he said this he looked directly at me, with his nose in the air.

It is winter now, and when in the early morning I find cakes and honey upon the breakfast-table, excellent as they are in their way, they are the better that they call up the wide landscape of those latter August days and of frosty Oetober, for I see less of the morning meal before me than of bees and buckwheat. 
T HAVE often wondered why the Indians 1 did not call November the month of dead leaves. The out-of-town world is full of them now. They replace the daisies and dandelions in the open fields, the violets and azaleas in the shady woods. They are a prominent feature of the village street. Many will cling to the trees the winter long, but millions are scattered over the ground. Even on the river I find them floating, borne slowly by the tide or hurrying across the rippled surface, chased by the passing breeze.

The pleasure-common to us all-we take in crushing them beneath our feet savors of heartlessness. Why should we not recall their kindness when, as bright-green leaves, each cast its mite of grateful shade, so dear to the rambler, and now, when they have fallen, let them rest in peace? We should 


\section{Dead Leaves}

not be ugly and revengeful merely because it is winter. There is nothing to fret us in this change from shade to sunshine, from green leaves to brown. The world is not dead because of it. While the sun looks down upon the woods to-day there arises a sweet odor, pleasant as the breath of roses. The world dead, indeed! What more vigorous and full of life than the mosses covering the rich wood-mould? Before me, too, lies a long-fallen tree cloaked in moss greener than the summer pastures. Not the sea alone possesses transforming magic ; there is also "a wood-change into something rich and strange." Never does the thought of death and decay centre about such a sight. The chickadee drops from the bushes above, looks the mossclad log over carefully, and, when again poised on an overhanging branch, loudly lisps its praises. What if it is winter when you witness such things? One swallow may not make a summer, but a single chickadee will draw the sting from any winter morning.

I never sit by the clustered dead leaves and listen to their faint rustling as the wind moves among them but I fancy they are whispering of the days gone by. What of the vanished 


\section{Dead Leaves}

springtide, when they first timidiy looked forth? They greeted the returning birds, the whole merry host of north-bound warblers, and what startling facts of the bird-world they might reveal! There is no eye-witness equal to the leaf, and with them lives and dies many a secret that even the most patient ornithologist can never gain. How much they overhear of what the birds are saying! to how much entrancing music they listen that falls not upon men's ears! What a view of the busy world above us has the fluttering leaf that crowns the tall tree's topmost twig! Whether in storm or sunshine, veiled in clouds or beneath a starlit sky, whatsoever happens, there is the on-looking leaf, a naturalist worth knowing could we but learn its language.

A word here as to the individuality of living leaves. Few persons are so blind as to have never noticed how leaves differ. Of every size and shape and density, they have varied experiences, if not different functions, and their effect upon the rambler in his wanderings is by no means always the same. At high noon, when the midsummer sun strives to parch the world, let the rambler stand 
first beneath an old oak and then pass to the quivering aspen, or pause in the shade of a way-side locust and then tarry beneath the cedar, at whose roots the sunshine never comes. It needs but to do this to realize that there are leaves and leaves: those that truly shelter and those that tease you by their fitfulness.

It is winter now and the leaves are dead; but, although blighted, they have not lost their beauty. Heaped in the by-paths of this ancient wood, they are closely associated with the pranks of many birds, and for this alone should be lovingly regarded. Even now I hear an overstaying chewink-for this is a warm wood the winter long-tossing them in little clouds about him as he searches for the abundant insects that vainly seek shelter where they have fallen. The birds seem to seek fun as well as food among the leaves. I have often watched them literally dive from the overhanging bushes into a heap of leaves, and then with a flirt of the wings send dozens flying into the air. It is hard to imagine any other purpose than pure sport. When, as often happens, two or three follow their leader, I always think of a string of boys diving 


\section{Dead Leaves}

or playing leap-frog. "Coincidence," cries old Prosy, with a wise shake of his head. Perhaps; but I think old Prosy is a fool.

The strange, retiring winter wren is equally a lover of dead leaves. He plays with them in a less boisterous manner, but none the less delights in tossing them to and fro. It is at such a time that a few notes of his marvellous summer song occasionally escape him. The white-throated sparrows fairly dance among or upon the heaped-up leaves, and play bopeep with the clouds of them they send aloft; and in February the foxie sparrows play the same pranks. Squirrels and mice are equally at home, and abandon all prudence when they frolic among the windrows. The more clatter and cackle, the better they are pleased. When freed from the restraint of fear, wild life is fun-loving to the very brim.

Dead leaves are never deserted unless the weather is extremely cold or a storm has prevailed until they are a sodden mat. Even from such a wetting they soon recover and respond to the passing breeze's gentlest touch. Dead leaves are the matured fruit of summer, and what an important part they really play as the year closes! They are not now of the 
air, airy, but of the earth, earthy. Dead, it is true, yet living. Passive, yet how active! They are whispering good cheer now to the sleeping buds that await the coming of a new year, and faithfully guard them when the storm rages. For such deeds we owe them our kindliest thoughts.

In the golden sunshine of this dreamy day the leaves have yet another visitor that makes merry with them. The little whirlwind, without a herald, springs laughingly upon them, even when the profoundest quiet reigns throughout the wood. Touched by this fairy's wand, the leaves rise in a whirling pillar and dance down the narrow path into some even more secluded nook. Dead leaves, indeed! Never did the wildest madcap of a courting bird play livelier pranks.

Time was when I would have searched the woods for winter-green and worn it gayly. I am content to-day to carry a withered leaf. 


\section{INDEX}

A. Allium, 77 .

Amelanchier, 140.

Andromeda, 57.

Ants, 14, 36.

Arbutus, 51 , 57, 62.

Arrowe-point, 156 .

Azalea, I4r.

B. Bear, 54 .

Beaver, 66.

Beech, 43.

Bircb, 54 .

Bittern, 73, 180 .

least, 42.

Bittersweet, 142.

Blackbird, 32, 41, 67, 75, 189 .

Blueberry, 64 .

Bluebird, 18, 67, 143, 197 .

Boneset, 155 .

Butterfies, 20, 156.

Buzzards, 67 .

C. Cardinal bird, $23,59,75,80,87,111,144$.

Cat-bird, 32, 59, 87, 1 37, 146.

Caterpillar, 133 .

0

$18 *$

209 
Catlinite, $150,15^{8 .}$

Cat-tail, 42.

Cedar, 64.

Celastrus, 142.

Centaury, 155.

Centipede, 57.

Chat, 32, 83 .

Cherry, wild, 43.

Chewink, 59, 80, 206.

Chickadee, 204.

Chimney-swift, 20.

Clay, 35.

Clethra, 141.

Cougars, 65.

Cow-bird, 93.

Crayfisb, 187, 190.

Crocus, 145.

Crowe, 11, 32, 47, 76, 86, 189, 200.

Cyperus, 77.

D. Day-flower, 195 .

Deer, 54, 179.

Deer-berry, I4I.

Deutzia, I4I.

Diver, 29.

Dodder, I 16, I 56 .

Dove, 24.

Dragon-fly, 156 .

Ducks, wild, 86; wood-, 56 .

E. Eagle, 24 .

Eel, 54 . 


\section{Index}

Elk, 179.

Elm, 43 .

F. "False-teetb," I4I.

Fincb, indigo, 72 ; purple, 59; thistle, 32.

Fly-catcher, 15, 32, 144.

Frogs, 58, 67 .

G. Galium, 77 .

Gerardia, 195.

Golden-club, 56 .

Grakle, 32, 75, 145, 189.

Grosbeak, rose-breasted, 59.

Gulls, 76.

Gum-tree, 66.

H. Harrier, 199.

Hawk, black, 17.

duck-, 24.

fisb-, 26, 32, 179, 181 .

sparrow-, 182 .

Heron, blue, 42 ; green, 25 ; night-, 189.

Herons, 41, 67, 187.

Herring, 67.

Hickory, 17, 44.

Holly, 5 I.

Honeysuckle, $1_{3} 6$.

Humming-bird, 136 .

Hyla, $5^{8}$.

I. Indian grass, 64 .

relics, $148,152,157,160$. 


\section{Index}

Ink-berry, 52.

Iris, 40.

Iron-weed, I 55 .

J. Fasper, 15 I.

Jay, blue-, 47.

Jerboa, 59 .

K. Kill-deer plover, 32, 67, 77, 95 .

Kingbird, 41, 197.

Kinglet, 65, 82 .

King-rail, 42, 199.

L. Leucothoe, I4I.

Lindera, 140.

Liquidambar, 54.

Loon, 67.

Lotus, 4I, 134 .

M. Magnolia, 66.

Maple, 28, 52, 72 .

Martin, 31, 143.

Mink, 53, I56, 179 .

Minnow, mud-, 39 .

Minnows, I 26, 191.

Mistletoe, 28, 66.

Mocking-bird, 32 .

Moss, club-, 57 ; reindeer, 54, 62 .

Mouse, meadow-, 17, 42, 156, 179. white-footed, 59.

Musk-rat, 29, 53, I56, 179.

Mussel, I9I. 


\section{Index}

O. Oak, 10, 21, 44, 64, 138 .

willow-, 53 .

Obsidian, I5O, 159 .

Opossum, 46, 59 .

Orioles, 71, 90, 144, 197.

Oven-bird, 135.

Orwl, barn, 123 .

P. Panther, 179 .

Partridge-berry, 54.

Pepper-busb, sweet, 141 .

Pike, 125.

Pine, Weymoutb, 30.

Pinxter forver, 141.

Pipilo, I13.

Plover, 188.

Plum, wild, 141.

Pontederia, 155 .

Poplar, Lombardy, 30.

Primrose, 155.

Pyxie, 57, 6r, 68.

Q. 2uail, 32, 200.

R. Rabbit, 44, 188, 196 .

Raccoon, 47, 187.

Rail-bird, 199.

Raven, 146.

Red-eye, 19, 32 .

Redstart, 32.

Reed-bird, 198 . 
Reeds, 155 .

Relics, Indian, 43.

Robin, 32, 47, 75, 146.

Rose-mallorw, $4 \mathrm{I}$.

Roses, 145.

S. Sand-piper, 25, $3^{8}$.

Saponaria, 77.

Sedge, 156.

Shad-busb, 140.

Snake, garter-, 27. water-, I 30, 179, 190.

Snow-birds, 67.

Sparrow, chipping, 32, 180 .

foxie, 207.

song-, $25,32,76,88,135$.

swamp-, 41 .

tree-, 59, 82, 198 .

white-throated, 59, $198,207$.

Sphagnum, 56, 57, 69.

Spice-rwood, 73, 140 .

Spiders, 37.

Spirea, 141.

Squirrel, fying-, 59.

Sunderw, 69.

Sunfish, 129.

Sunflozver, 41, 155 .

Swallorw, bank, 93 ; barn, 94.

T. Tanager, scarlet, 53, 144 .

Tea-berry, 52 .

Teal, blue-zvinged, 190. 


\section{Index}

Thorn, white, 141.

Thrusb, brown, 32, 72, 82 .

Thrushes, 71, 144.

Titmouse, 20, 67, 75 .

Trout, 127.

Trumpet-creeper, 136 .

Tulip-tree, 43.

Turkey-buzzard, 32.

Turtle, snapping-, I32, 179.

V. Vireo, red-eyed, 32, 90; white-eyed, II2.

W. Warbler, spotted, 32, 51 .

tree-creeping, 87.

Warblers, 51, 73, 205.

Weasel, ${ }^{5} 6$.

Whippoorrvill, 72.

Winter-green, 62, 69 .

Wolf, 179.

Wood-robin, 18 .

Wren, 31, 72, 142.

Carolina, 79.

marsb-, 41 .

winter, 207. 


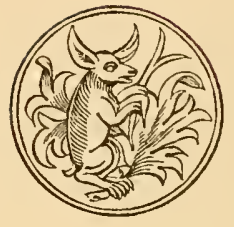







LIBRARY OF CONGRESS

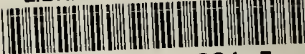

$\begin{array}{llll}0 & 015 & 775 & 2315\end{array}$ 